\author{
January 2019, VOLUME 7, ISSUE 1, 57 - 91 \\ E-ISSN NO: $2289-4489$
}

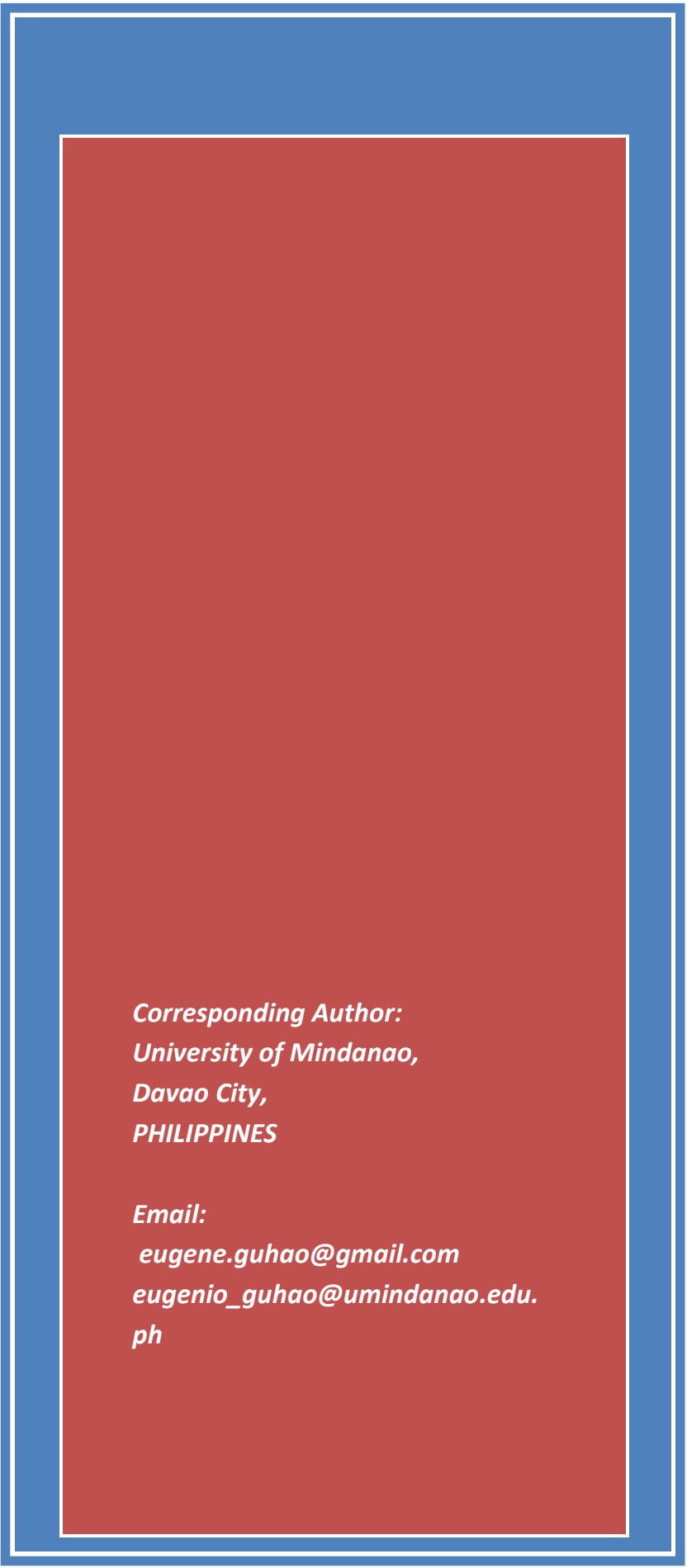

\title{
ORGANIZATIONAL COMMITMENT OF PUBLIC SCHOOL TEACHERS: A STRUCTURAL EQUATION MODELING ANALYSIS
}

Eugenio S. Guhao, Jr. (PhD)

\begin{abstract}
The study determined the level of organizational commitment of public school teachers in their identity orientation, immediacy behaviour, and teacher selfefficacy in Region XI, Mindanao, Philippines. Using descriptive-correlation and Structural Equation Modeling, the researcher selected 400 public elementary school teachers from the region through stratified proportionate sampling. Findings revealed high levels of identity orientation, immediacy behaviour, organizational commitment and a very high level of teacher self-efficacy. A significant relationship was shown between all latent exogenous variables and organizational commitment; all latent exogenous variables significantly influenced the endogenous variable organizational commitment. The most parsimonious model 5 conveyed a generalized new concept that teacher commitment was primarily grounded on continuance and affective organizational commitment, defined from the nature of identity orientation which was influenced by social and collective identity, and which must be highly reinforced with verbal and nonverbal immediacy behaviour of teachers. Structural Model 5, which depicted the direct causal relationships of identity orientation and immediacy behaviour to the organizational commitment of teachers, was found to be the best fit and most parsimonious model.
\end{abstract}

Keywords: Identity Orientation, Immediacy Behaviour, Teacher Self-Efficacy, Organizational Commitment, Structural Equation Modeling, Education, Philippine 


\section{MALAYSIAN ONLINE JOURNAL OF EDUCATIONAL MANAGEMENT (MOJEM)}

\section{INTRODUCTION}

The problem in most organizations is when employees tend to become lazy and does not like to work. It is a common situation in most companies. In most cases, employees exhibit a low level of organizational commitment (Huff \& Kelley, 2003; Mahdi, Ismail, Jugie, \& Sari, 2017). Organizational commitment is vital for any organization. Studies revealed that it enhances organizational productivity due to increased motivation and performance of employees, thus increasing employee self-efficacy (Dixit \& Bhati, 2012; Ulrich \& Smallwood, 2003) which then significantly predicts organization commitment (Murthy, 2014). Employees usually go beyond what is expected of them because they have the sense of belongingness and their goals are parallel with the organization (Cato \& Gordon, 2012; Kinjerski \& Skrypnek, 2006). Furthermore, the organizational commitment of the workforce brings life to organizations, making them competitive, and allowing them to overcome challenges head-on (Choi \& Lee, 2011; Jehanzeb, Rasheed \& Rasheed, 2013; Nicholson, 2009). On the other hand, low employee commitment results in job dissatisfaction, consequently increasing employee turnover (Nicholson, 2009).

Employee commitment poses more challenges to organizations today. Employers are challenged to develop strategies to motivate employees in order to create emotional attachment and satisfaction in their work. Today's employees hop from one company to another in their career more often than before. Employers are not sure how long people will remain in the company once they are hired (Anttila, 2015). Moreover, it is more challenging for companies to make younger people, especially millennials to stick to the organization since they are more committed to their profession than to the organization (Laurinolli, 2010, as cited in Suryani, 2018).

In the Philippines, Tolentino (2013) investigated the organizational commitment among employees in a chartered state university, including the teachers. The results revealed that the teachers have a strong desire to stay in the university. However, they only had a moderate need to stay since there are other available opportunities outside. The teachers had a stronger normative and affective commitment than the administrative staff, but only affective commitment correlated significantly with job performance. In the region, Chavez (2012) gathered data from teachers in randomly selected academic institutions and discovered that leadership behaviour, job satisfaction and burnout highly correlated with organizational commitment. His study was undertaken because a previous study of Tabuso (2007) revealed that teachers have the least degree of attachment despite the fact that the school provides them with economic security. Dalanon et al. (2018) also researched about teacher commitment in a rural K-12 school in the central region of the country, but only as part of organizational climate. They found that the young educators had high commitment and optimism, though no correlation was shown between the variables age, sex, designation and experience and the school climate. Therefore, in the Philippines, with regards to the factors affecting organizational commitment of teachers, particularly the relationships between emotional attachment, identity and self-efficacy, a dearth still exists in the database as the constructs are still difficult to identify.

Even though previous research findings showed that organizational commitment significantly affects productivity, and employees' motivation makes organizations more competitive, more than a third of workers around the world have declared that they have low levels of organizational commitment. Only 8 out of 100 (8\%) are highly committed to their organizations (Fornes, Rocco, \& Wollard, 2008). In the USA, levels of company commitment are significantly lower than those of big economies globally, making this country less competitive in the global arena (Fornes \& Rocco, 2004). This study therefore hopes to look deeper into the organizational commitment of Philippine public school teachers through an analysis of structural equation models.

\section{Conceptualizing Organizational Commitment}

The study was developed in line with three propositions and one theory: The first anchor proposition states that there is a relationship between self-efficacy, work engagement and organizational commitment (Dabas \& Pandey, 2015; Garcia, 2015; Murthy, 2014); the second proposition is that identity is directly related with self-efficacy. 


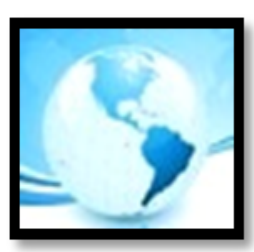

\section{MALAYSIAN ONLINE JOURNAL OF EDUCATIONAL MANAGEMENT (MOJEM)}

Belongingness to an organization, family income, and collective identity are significant predictors of self-efficacy (Klassen \& Chiu, 2010). There is a direct link between identity orientations with efficacy which in turn has a direct connection with organizational commitment. (Garcia, 2015). On the other hand, immediacy behaviour anchors on Mehrabian's (1981) Implicit Communication Theory. This theory put forth the idea that communication is categorized into explicit and implicit communication or merely verbal and nonverbal classification. Furthermore, teacher immediacy increases student motivation to learn and improves students liking the teacher as well as the subject and decreases anxiety to participate in class activities, thereby increasing student perception of teacher effectiveness, enhancing teacher self-efficacy which in turn predicts organizational commitment (Brophy, 2004; Butland \& Beebe, 1992; Lopez, 2004; Rodriguez, Plax, \& Kearney, 1996, as cited in Velez \& Cano, 2008).

Studies show that most teachers have low self-efficacy because of job burnout caused by teaching-related stress. If teachers want to improve self-efficacy, the issue of burnout must be duly addressed (Brouwers \& Tomic, 2000; Schwarzer \& Hallum, 2008; Skaalvik \& Skaalvik, 2007). Strain relative to job stress results in burn-out and a low level of efficacy. Due to the demands of teaching, mentors who lack the appropriate stress management strategies are directly affected by this condition. School heads must develop policies and approaches to help teachers cope with job stress effectively and boost their sense of self-efficacy, given the demands of the profession (Eslami \& Fatahi, 2008). Similarly, as one of the predictors of organizational commitment, teacher self-efficacy has a significant effect on students' achievement (Ryan, Kuusinen, \& Bedoya-Skoog, 2015; Caprara, Barbaranelli, Steca, \& Malone, 2006). Likewise, studies show that student misbehaviour is the usual cause of the burnout new teachers experience (Jacobson, 2016; Johnson, Claus, Goldman, \& Sollitto, 2017; Larrivee, 2012; Prastika, 2017). Generally, for Garcia (2015) self-efficacy is a determinant of organizational commitment.

Immediacy is a communication behaviour, further classified into verbal and nonverbal, otherwise known as explicit and implicit communication. It enhances closeness between the sender and the receiver of the message. Precise communication conveys the content while implicit communication carries the emotions and feelings of the sender; the combined term for these two types is immediacy (Butland \& Beebe, 1992; Mehrabian, 1981; Witt, Wheeless, \& Allen, 2004, Mullane, 2014). Teacher immediacy increases the students' motivation to learn and improves students liking the teacher as well as the subject and decreases anxiety to participate in class activities, thereby increasing student perception of teacher effectiveness which in turn enhances teacher self-efficacy and consequently predicts employee commitment (Brophy, 2004; Butland \& Beebe, 1992; Lopez, 2004; Rodriguez, Plax, \& Kearney, 1996, as cited in Velez \& Cano, 2008).

On the other hand, organizational task and reward structure explain how individual identity orientation is activated, specifically collective and personal relational identity orientations, which benefits the organization and prevents the ill effects of diversity (Brickson, 2000). Research shows that identity orientation predicts citizenship performance behaviour; if a person has high collective identity orientation, he/she has high motivation to work for the best interest of the organization and identifies as an organization man.

According to Dabas and Pandey (2015), employees have self-efficacy when they feel that they can accomplish any job assigned to them using their actions and ability. This results in employees becoming committed to their jobs, thereby promoting organizational performance. How teachers see themselves also correlates with their actual accomplishments and job skills Klassen and Chiu (2010). Therefore, their self-efficacy should be maximized by exposing them to seminars, group dynamics and stress management activities. For Garcia (2015), employees' gender, workload and years on the job do not significantly affect organizational commitment, while Mehrabian's Implicit Communications theory (1981) points to the importance of the teacher's warmth, care and genuine interest in the student in increasing student achievement.

Summing up, based on the above propositions and theories, the teachers' skills affects their organizational commitment, and how they see themselves is related to how skilled they are. This in turn affects their commitment to their school; at the same, time, good verbal and non-verbal communication skills makes students 


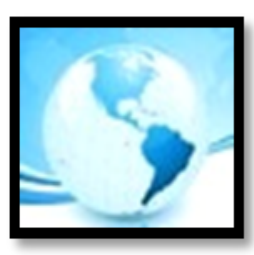

\section{MALAYSIAN ONLINE JOURNAL OF EDUCATIONAL MANAGEMENT (MOJEM)}

perceive them as effective, and this ultimately enhances their skills further, leading to greater organizational commitment.

\section{Model Building}

The model fit on organizational commitment is limited to the three causal exogenous variables: identity orientation, immediacy behaviour of school heads, and teacher sense of self-efficacy. The study was conducted in the public school setting in Region XI, Philippines, and revolved around the indicators from three adapted questionnaires.

The first exogenous variable is immediacy behaviour, measured by two indicators from Velez and Cano (2008): verbal immediacy, and nonverbal immediacy. Verbal immediacy is the explicit oral messages often involving personalized two-way communication, while nonverbal immediacy is the use of subdued behaviours to relay a specific condition, connection or feeling (Mehrabian, 1981).

The second exogenous variable is teacher self-efficacy, measured by four indicators from Schwarzer and Hallum (2008) based on Bandura's Self-efficacy Theory (1986): job accomplishment; coping with stress; social interaction with students, parents and colleagues, and skill development on the job. Job Accomplishment refers to the ability to teach all relevant subjects to diverse students; Coping with Stress is the ability to implement creative means to cope with job constraints; Social Interaction with Students, Parents, and Colleagues is the ability to address student needs through positive relationships with co-teachers and parents, and Skill Development on the Job is the ability to continuously develop oneself to become more capable in helping students address their needs.

The third exogenous variable is identity orientation measured by four indicators from Cheek and Briggs' (2013) Aspects of Identity Questionnaire (AIQ-IV): Personal identity, Relational Identity, Social Identity, and Collective Identity orientation. Personal Identity is the feeling of the individual of being a unique person and distinct from others; Relational Identity, having caring relationships with others; Social Identity, one's social behaviour, the way one acts with people, while Collective Identity is identifying oneself with a group.

The latent endogenous variable is organizational commitment with four observed indicators adopted from Jaros (2007) based on Meyer and Allen's Model of Organizational Commitment: Affective Commitment, Continuance Commitment, Indebted Obligation Dimension, and Moral Imperative Dimension. Affective Commitment refers to emotional attachment to the organization; Continuance Commitment, the degree to which one believes he ought to stay with the organization; Indebted Obligation Dimension, owing allegiance to the organization, while Moral Imperative Dimension refers to one's principle that compels him how to act.

Hypothesized Model 1 (see Figure 1) models the direct causal relation of identity orientation, immediacy behaviour, and teacher self-efficacy towards organizational commitment. 


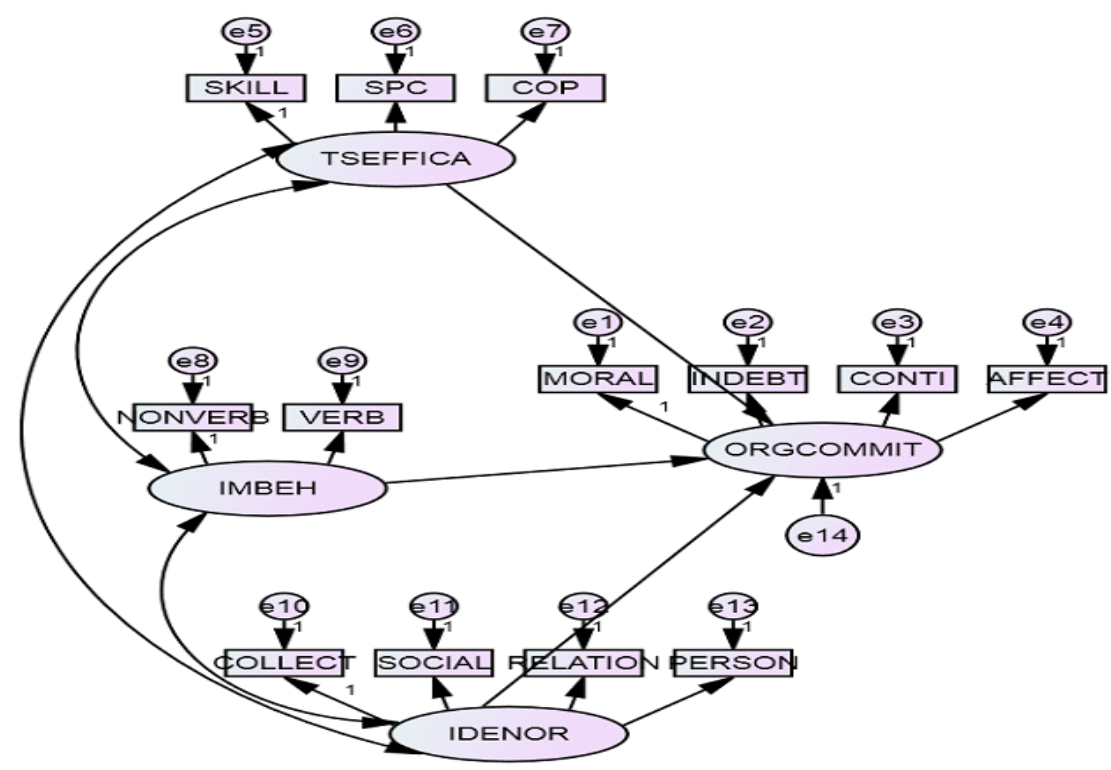

Figure 1. Model 1 for Direct Causal Relationship of the exogenous and endogenous variables.

IDENOR: Identity Orientation; COLLECT: Collective; SOCIAL: Social; RELATION: Relational; PERSON: Personal; TSEFFICA:Teacher Self-Efficacy; SKILL: Skill Developent on the Job; SPC:Social Interactions with Parents and Colleagues; COP:Coping with Stress: IMBEH: Immediacy Behaviour; NONVERB: Nonverbal; VERB: Verbal; ORGCOMMIT: Organizational Commitment; MORAL: Moral Imperative Dimensi on; INDEBT: Indebted Obligation Dimension; CONTI: Continuance; AFFECT: Affective

Hypothesized Model 2 (see Figure 2) models the interrelationships between the latent exogenous variables teacher self-efficacy and identity orientation and its direct causal relation to the endogenous organizational commitment. 


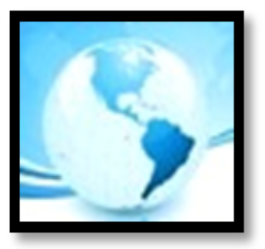

\section{MALAYSIAN ONLINE JOURNAL OF EDUCATIONAL MANAGEMENT (MOJEM)}

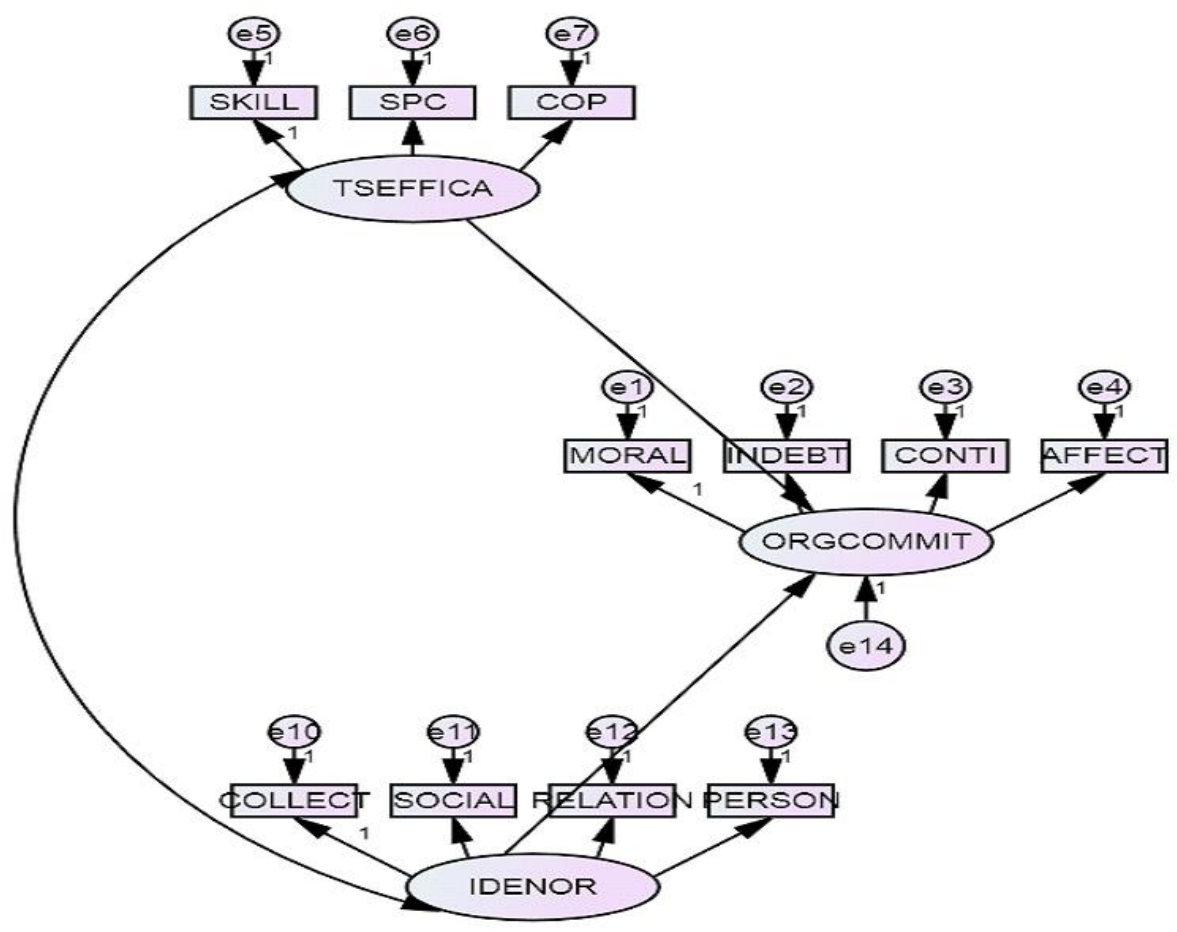

Figure 2. Model 2 showing the correlation between two exogenous variables and its Direct Causal Relationship to the endogenous variable.

IDENOR: Identity Orientation; COLLECT: Collective; SOCIAL:Social; RELATION: Relational; PERSON: Personal; TSEFFICA:Teacher Self-Efficacy; SKILL: Skill Developent on the Job; SPC:Social Interactions with Parents and Colleagues; COP:Coping with Stress; ORGCOMMIT: Organizational Commitment;

MORAL: Moral Imperative Dimension; INDEBT: Indebted Obligation Dimension; CONTI:

Continuance; AFFECT: Affective

Hypothesized Model 3 models the correlation between immediacy behaviour and identity orientation and its direct causal relationship to organizational commitment (see Figure 3). 


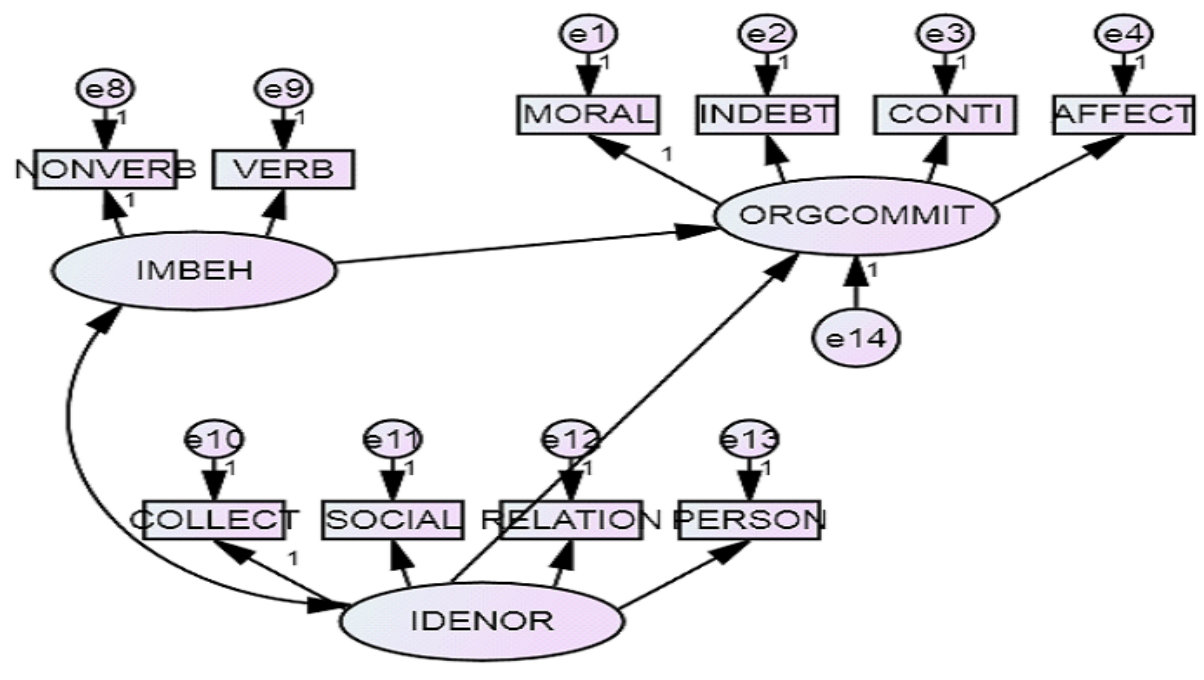

Figure 3. Model 3 showing the Correlation between 2 exogenous variables and its Direct Causal Relationship to the endogenous variable

IMBEH: Immediacy Behaviour; NONVERB: Nonverbal; VERB:Verbal; IDENOR: Identity Orientati on; COLLECT: Collective; SOCIAL: Social; RELATION: Relational; PERSON:

Personal; ORGCOMMIT: Organizational Commitment; MORAL: Moral Imperative Dimensi on; INDEBT: Indebted Obligation Dimension; CONTI: Continuance; AFFECT: Affective

Hypothesized Model 4 models the correlation between teacher self-efficacy and immediacy behaviour and its direct causal relationship to organizational commitment (see Figure 4). 


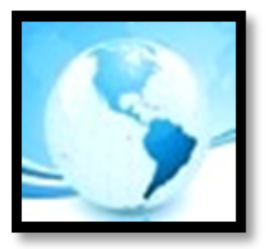

\section{MALAYSIAN ONLINE JOURNAL OF EDUCATIONAL MANAGEMENT \\ (MOJEM)}

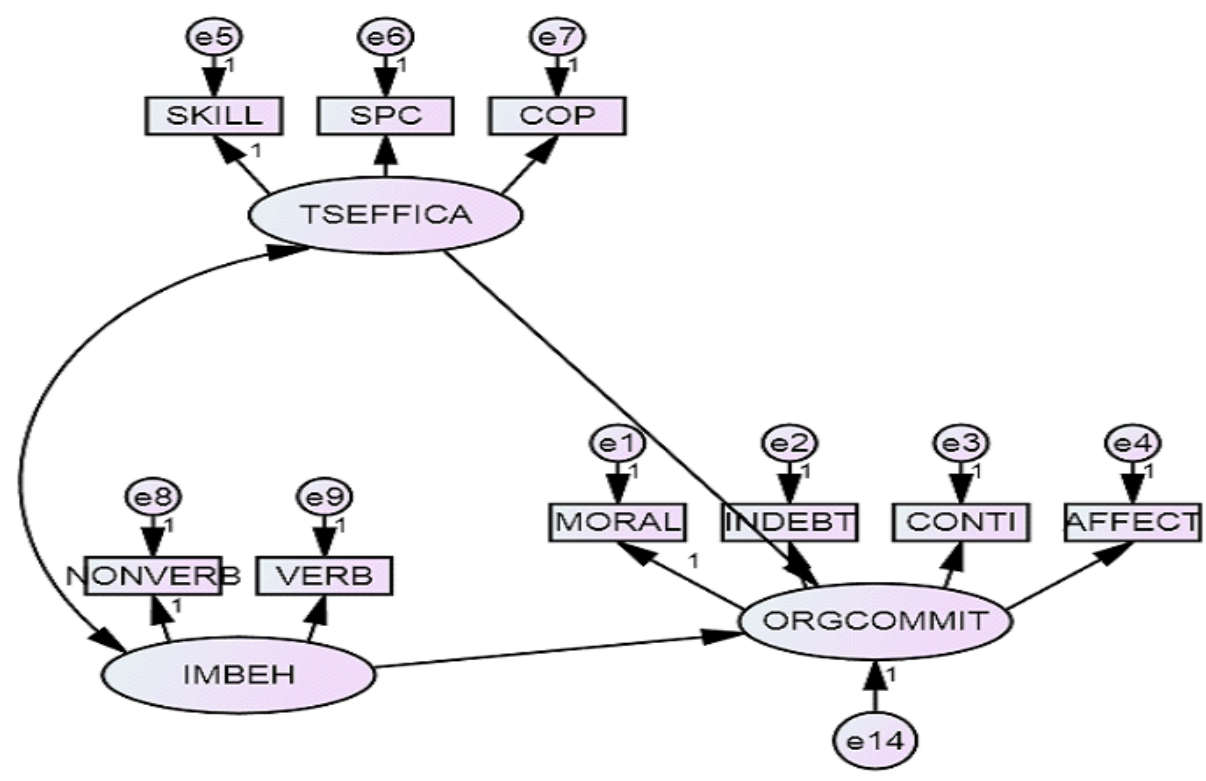

Figure 4. Model 4 showing the Correlation between two exogenous variables and its Direct Causal Relationship to the endogenous variable

TSEFFICA:Teacher Self-Efficacy; SKILL: Skill Developent on the Job; SPC: Social Interactions with Parents and Colleagues; COP:Coping with Stress; IMBEH: Imeediacy Behaviour; NONVERB:Nonverbal; VERB: Verbal; ORGCOMMIT: Organizational Commitment; MORAL: Moral Imperative Dimension; INDEB T: Indebted Obligation Dimension; CONTI: Continuance; AFFECT: Affective

Finally, Hypothesized Model 5 shows the correlation between immediacy behaviour and identity orientation and its direct causal relationship to organizational commitment (see Figure 5). 

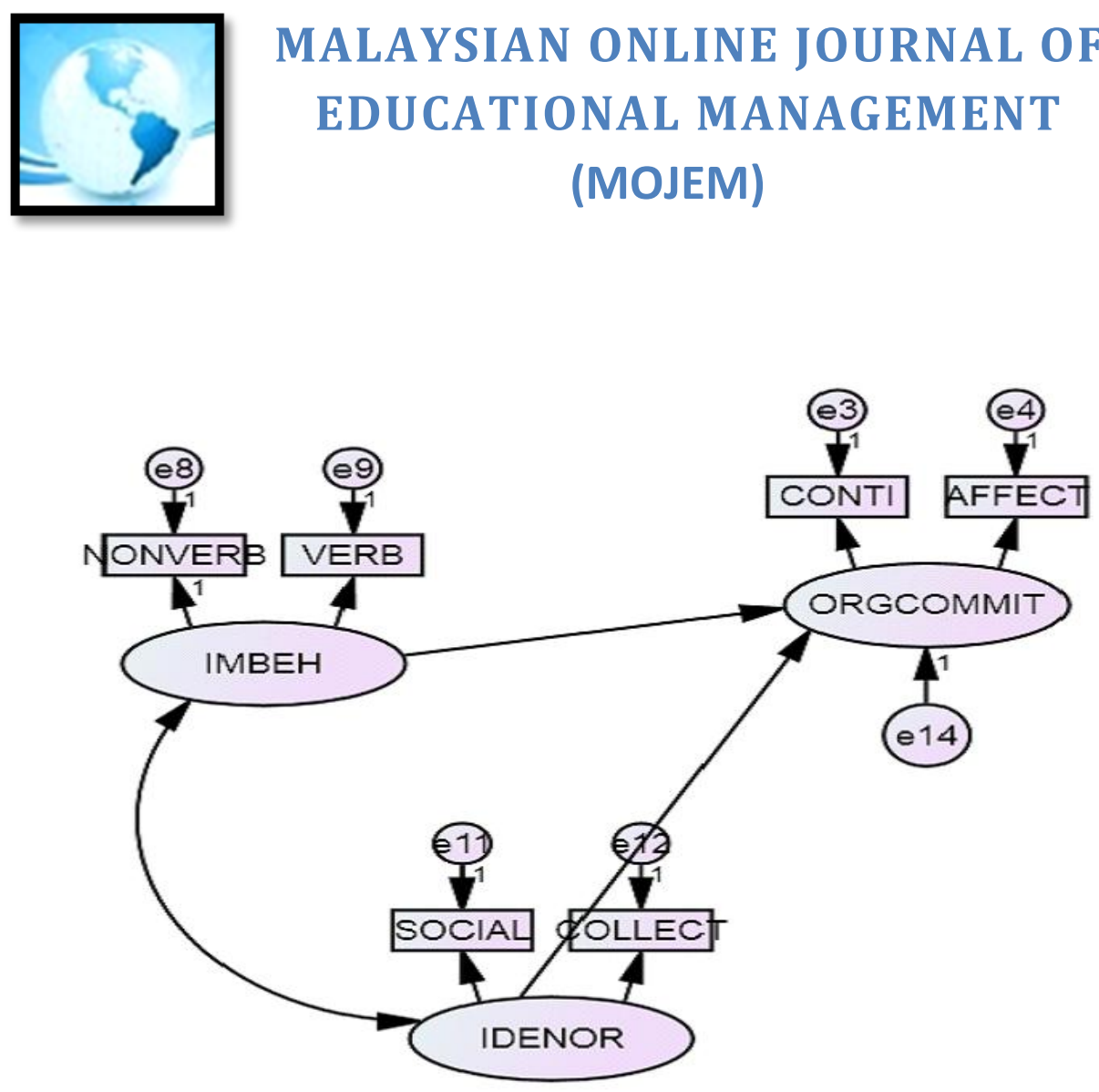

Figure 5. A Model showing the correlation between two exogenous variables and its Direct Causal Relationship to the endogenous variable

IDENOR: Identity Orientation; SOCIAL:Social; COLLECT: Collective; ORGCOMMIT:

Organizational Commitment; CONTI: Continuance; AFFECT: Affective; IMBEH: Immediacy Behaviour; NONVERBAL: Nonverbal; VERB: Verbal

Based on the conceptual models, the research had the following objectives: to know the level of identity orientation of public school teachers; the level of immediacy behaviour of public school teachers; the level of teacher efficacy; and the level of teacher organizational commitment. It also seeks to show significant relationships among teacher identity orientation and organizational commitment; immediacy behaviour and organizational commitment, and teacher self-efficacy and organizational commitment. It also aims to know the significant influences of the independent variables on the dependent variable and the best fit model on organizational commitment.

\section{METHOD}

\section{Research Design}

This study utilized the primary research design employing the quantitative research method. First, the descriptivecorrelational method of research was used. This method provides an accurate picture of the status or characteristics of a situation or phenomena and describes the variables that exist in a given situation (Johnson \& Christensen, 2008). Correlation research determines the strength of a relationship between variables and how well the two variables are correlated. 


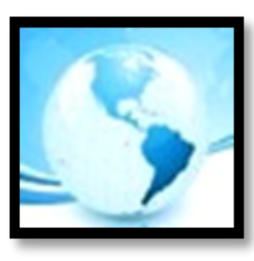

\section{MALAYSIAN ONLINE JOURNAL OF EDUCATIONAL MANAGEMENT (MOJEM)}

To generate the best fit model, a structural equation model was used. Structural Equation Model is the most appropriate tool for it tests whether the observed relationships among a set of variables conform to a theoretical prediction about how those variables should be causally related (Hooper, Coughlan, \& Mullen, 2008). This causalcomparative research design is used to establish a model regarding organizational commitment as influenced by identity orientation, immediacy behaviour, and teacher self-efficacy. The questionnaire was the best method for data gathering. In this context, the Structural Equation Modelling was more appropriate to utilize since the focal point of this research, being a four-variable study, was to produce a model on organizational commitment and to measure the degrees of relationships between the independent variables identity orientation, immediacy behaviour, teacher self-efficacy and the dependent variable, organizational commitment.

Following the rule of thumb for the number of respondents appropriate for SEM which should be between $300-$ 400 (Yuan \& Hayashi, 2010), the researcher tried to work backwards by making use of the appropriate sample per strata in quota sampling which is 10 . Following this line of thought, the required number was 40 schools with 10 respondent-teachers from each school.

The study was conducted with the assistance of the school heads and education supervisors coming from the school divisions of Region XI Philippines. They distributed the questionnaires in their respective divisions during the district meetings of the teachers. The school heads first obtained permission to conduct the study through their respective offices. Data were then collated and tabulated for statistical analysis. Afterwards classified, analysed and interpreted using the following statistical tools: mean, Pearson Product Moment Correlation, Multiple Linear Regression, and Structural Equation Mode

\section{Population and Sampling}

The study was conducted in 40 selected schools from 9 public school divisions of the Department of Education (DepEd) in Region XI, Philippines, in 2016-2017 which are: Mati City/Davao Oriental, Tagum City, Davao del Norte, Panabo City, Island Garden City of Samal (IGACOS), Digos City, Davao del Sur, Compostela Valley, and Davao City.

The respondents of this study were 400 public elementary school teachers of the different divisions in Region XI; the researcher has identified the number of schools in every division in the region (see Table 1). Simple random sampling was used to determine the number of schools perdivision who would participate. As shown in Table 1, the teachers of the different schools in the divisions in Region XI were the subjects for the study. Forty respondent schools were involved in the research with ten teachers for each school, totalling 400 teachers. These was the prescription of Changing Minds (2012) that a quota sample of 10 per subgroup is needed to avoid bias in sampling. The 40 schools involved in this study were taken from the nine divisions of Region XI through proportionate sampling with the number of schools per division as the reference point.

Davao City had the highest number of respondents with 90 (23\%). Compostela Valley had 80 (20\%), while Davao Oriental/Mati City had 70 respondents (18\%). On the other hand, Davao del Sur had 60 respondents (14\%), while Davao del Norte had 40 respondents (11\% each). Meanwhile, Panabo and Igacos each had the same number of respondents with $20(4 \%)$. Lastly, Digos and Tagum City had the smallest number of respondents with 10 (2\%) each. 


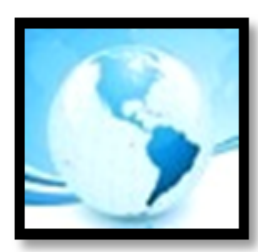

MALAYSIAN ONLINE JOURNAL OF

EDUCATIONAL MANAGEMENT

(MOJEM)

Table 1

Distribution of Respondents

\begin{tabular}{lllll}
$\begin{array}{l}\text { Divisions of } \\
\text { Reg. XI }\end{array}$ & $\begin{array}{l}\text { No. of schools } \\
\text { Per division }\end{array}$ & $\begin{array}{l}\text { No. of respondent } \\
\text { schools }\end{array}$ & $\begin{array}{l}\text { Sample } \\
\text { per school }\end{array}$ & Percent \\
\hline $\begin{array}{l}\text { Compostela } \\
\text { Valley }\end{array}$ & 60 & 8 & 10 & $20 \%$ \\
$\begin{array}{l}\text { Davao del Norte } \\
\text { Davao del Sur }\end{array}$ & 34 & 4 & 10 & $11 \%$ \\
Davao Oriental/Mati & 55 & 6 & 10 & $14 \%$ \\
City & 70 & 7 & 10 & $18 \%$ \\
Davao City & 6 & 9 & & $23 \%$ \\
Digos City & 12 & 1 & 10 & $2 \%$ \\
Panabo City & 7 & 2 & 10 & $4 \%$ \\
Tagum City & 13 & 1 & 10 & $2 \%$ \\
IGACOS & 299 & & 10 & $4 \%$ \\
& & 40 & 10 & $100 \%$ \\
\hline TOTAL & 299 & & 400 & \\
\hline
\end{tabular}

\section{Instrumentation}

There were four instruments used in this study. All four of them has been adapted to fit the local setting: 1 ) Immediacy behaviour (Velez \& Cano, 2008) with 29 items; 2) Teacher self-efficacy (Schwarzer \& Hallum, 2008), consisting of 10 items; 3) Identity orientation (Cheek \& Briggs's Aspects of Identity Questionnaire (AIQ-IV) (2013), with 7 items and organizational commitment (Jaros, 2007) based on Meyer and 4) Model of Organizational Commitment by Meyer and Allen (1997), consisting of 19 items.

Table 2

The goodness of Fit Standard Criterion Statistics for Structural Models

\begin{tabular}{lc} 
Chi-square & large value \\
\hline P value & $>0.05$ \\
Chi Square/Degrees of Freedom (CMIN/DF) & $<5$ \\
Normative Fit Index & $>0.95$ \\
Comparative Fit Index & $>0.95$ \\
Goodness of Fit Index & $>0.95$ \\
Tucker-Lewis Index & $>0.95$ \\
Root Mean Square Error of Approximation (RMSEA) & $<0.05$ \\
P close & $>0.50$
\end{tabular}

In order to identify the best fit model, all the values of the given indices must fall within each criterion.

\section{Data Analysis Procedure}

Multiple Linear Regression is a statistical tool in which a mathematical model is developed in an attempt to predict a dependent variable by two or more independent variables or in which at least one predictor is non-linear. It was used to determine the significance of the influence of the three independent variables on the dependent variable. Structural Equation Modeling (Maximum Likelihood) is a multivariate technique which combines the aspects of multiple regression (examining dependence relationships) and factor analysis to estimate a series of interrelated dependence relationships simultaneously (Hair, Sarstedt, Ringle, \& Mena, 2012). It was used to test the 


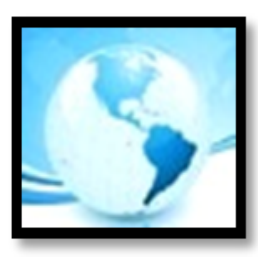

\section{MALAYSIAN ONLINE JOURNAL OF EDUCATIONAL MANAGEMENT (MOJEM)}

hypothesized model and to determine the best fit model of organizational commitment of teachers. In order to evaluate the goodness of fit of the hypothesized models, the following indices were considered: Chisquare/degrees of freedom ( $\left.x^{2} / d f\right)$, Goodness of Fit Index (GFI), Normed Fit Index (NFI), Tucker-Lewis Index (TLI), Comparative Fit Index (CFI), and Root Mean Square Error of Approximation (see Table 2).

The four questionnaires were subjected to the Alpha-Cronbach test for reliability. They were administered to a separate group of 30 public school teachers, and gained the following scores: for identity orientation, .909; for selfefficacy, .892; for immediacy behaviour, .852; and for organizational commitment, .911.

A qualified panel of experts validated the questionnaires in the academy and in the research locale of the study, and the four questionnaires each obtained a score of 4.0 (Very Good).

\section{FINDINGS AND DISCUSSION}

The 400 respondents in this study were all public school teachers from 40 selected schools in the region. Out of this number, there were more females, 287(71.75\%) than males, 113(28.25\%). For their ages, 21 of them (5.25\%) were 60-69 years old; 66(16.50\%), 50-59 years old; $131(32.75 \%), 40-49 ; 107(26.75 \%)$ 30-39; and 75(18.75\%), 20-29 years old. The median percentage for age was estimated to be $40-49$ years. For educational attainment, 400 (100\%) had a bachelor's degree. In length of service, 3 of them (.75\%) had been teaching for more than 40 years, $53(13.25 \%)$ for $30-39$ years, $167(41.75 \%)$ for $20-29$ years, $109(27.25 \%)$ for $10-19$ years, and $68(17 \%)$ for less than a year. The median percentage for length of service was $20-29$ years.

\section{Level of Identity Orientation}

Table 3 presented the level of identity orientation of teachers measured by its four indicators: personal, relational, social and collective identity. The overall mean rating of identity orientation was high or 4.08 with a standard deviation of 0.438 distributed among the four indicators with mean scores: 4.37 or very high for personal identity, 4.21 or very high for relational identity, 3.92 or high for collective identity, and 3.83 or high for social identity orientation.

A high level of identity orientation is fundamental to individuals (Cheek, 1989; Chew, 2007). It is needed to see how an individual perceives his/her personal qualities in constructing his self-definition. According to Cheek and Briggs (2013), there are four major aspects of identity orientations: Personal, Relational, Social and Collective. Furthermore, Hsieh (2015) averred that there was an implication of the teacher's individual orientation in classroom practice. The teachers varied in the degree they perceived the importance of each orientation on classroom management. These variations caused differences in their practices as they played out their respective roles as teachers and in their dealings with students. 


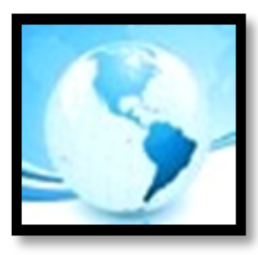

Table 3

Level of Identity Orientation

\begin{tabular}{|c|c|c|c|}
\hline Items & SD & Mean & D.E. \\
\hline $\begin{array}{l}\text { Personal Identity } \\
\text { Orientation }\end{array}$ & 0.423 & 4.37 & Very High \\
\hline $\begin{array}{l}\text { Relational Identity } \\
\text { Orientation }\end{array}$ & 0.484 & 4.21 & Very High \\
\hline $\begin{array}{l}\text { Social Identity } \\
\text { Orientation }\end{array}$ & 0.651 & 3.83 & High \\
\hline $\begin{array}{l}\text { Collective Identity } \\
\text { Orientation }\end{array}$ & 0.586 & 3.92 & High \\
\hline Overall & 0.438 & 4.08 & High \\
\hline
\end{tabular}

A very high personal identity orientation meant that the teachers had a very high sense of personal values and moral foundation as they practice the ethical standards of their profession, very apparent in the ways they teach the students, i.e., guided by their personal goals and hopes for the future. This concurs with the research by Veugelers (2008) that argued curriculum delivery, classroom climate, and environment should revolve around the teaching and practice of moral values by the teachers as paragons of morality inside and outside the classrooms. Moreover, an effective teacher has a very high level of self-knowledge, ideas about what kind of person one is and has feelings of being a unique person. Cranton (2001) espouses that to achieve a personal and professional identity that connects teaching, the teacher must find strategies to understand the "self" that would interrelate with the teaching-learning process. She further suggests a step-by-step approach on how to discover and disclose one's authentic self in the classroom that includes understanding one's values and experience, uniting self and teacher, and connecting with students. Finally, Powell, Cantrell and Adams (2001) described this approach as an excellent framework for disclosing one's identity as a teacher into instruction to create prospects for heightened student learning and learning empowerment.

\section{Level of Immediacy Behaviour of Teachers}

In Table 4, it is shown the level of immediacy behaviour of teachers with an overall mean rating of 3.87 or high. Verbal behaviour obtained a 4.13 mean level or high followed by nonverbal behaviour with a mean score of 3.61 or high.

Table 4

Level of Immediacy Behaviour of Teachers

\begin{tabular}{llll}
\hline SD & Mean & $\begin{array}{l}\text { Descriptive } \\
\text { Level }\end{array}$ \\
\hline Verbal items & 0.448 & 4.13 & High \\
Nonverbal items & 0.547 & 3.61 & High \\
Overall & 0.424 & 3.87 & High
\end{tabular}

High verbal immediacy behaviour of teachers encourages students to interact in the classroom, while the teachers share their ideas and give positive feedback to students' arguments while recognizing the good works the students 


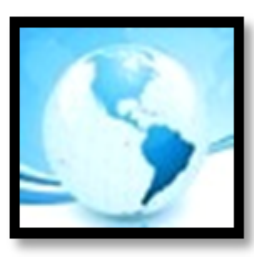

\section{MALAYSIAN ONLINE JOURNAL OF EDUCATIONAL MANAGEMENT (MOJEM)}

have shown. This is similar to the findings by Roberts and Friedman (2013) who believed that in higher education institutions where professors were more immediate in their classroom approaches, there was more frequent classroom participation and interaction from their students due to the warmth that professors exuded in the process. In this kind of atmosphere, as posited by Reyes, Brackett, Rivers, White and Salovey (2012), Pianta, Hamre, and Allen (2012) and Witt, Schrodt, Wheeless and Bryand (2014), students feel welcome to participate in classroom discussion which ultimately results in positive student outcomes through improved active student engagement. This affirms the argument by Mullane (2014) that both verbal and nonverbal teacher immediacy behaviours independently predict or cause a level of affective learning and cognitive learning, and affective learning predicts or creates cognitive learning.

Researches by York (2015) and Furlich (2016) further strengthen this. For the latter, only the professors' verbal immediacy behaviours exhibited a direct linear regression on students' learning motivation while the former revealed that there was sufficient evidence linking the instructor's nonverbal immediacy behaviour and student learning which could be very beneficial to the success of higher education institutions.

\section{Level of Teacher Self-Efficacy}

Table 5 showed the level of teacher self-efficacy with an overall mean level of 4.26 or very high and a standard deviation of 0.496 . The indicators that define teacher self-efficacy were: skill development on the job, 4.38 or very high; job accomplishment, 4.30 or very high; coping with stress, 4.20 or very high; and Social Interaction with students, parents, and colleagues, 4.17 or high.

Table 5

Level of teacher Self-Efficacy

\begin{tabular}{llll}
\hline Items & SD & Mean & Descriptive level \\
\hline Job accomplishment & 0.547 & 4.30 & Very High \\
$\begin{array}{l}\text { Coping with stress } \\
\begin{array}{l}\text { Social Interaction } \\
\text { with students, parents } \\
\text { and colleagues }\end{array}\end{array}$ & 0.573 & 4.20 & Very High \\
$\begin{array}{l}\text { Skill Development on } \\
\text { the job }\end{array}$ & 0.601 & 4.17 & High \\
Overall & 0.496 & 4.38 & Very High \\
& & 4.26 & Very High \\
\hline
\end{tabular}

Schwarzer and Hallum (2008), based on Bandura's Self-efficacy Theory (1986) recognized that in order for teachers to have a high level of self-efficacy, they should have a strong sense of job accomplishment, stress coping mechanisms, and a highly dynamic social interaction with students, parents, and colleagues. Likewise, a high level of teacher self-efficacy promotes a high level of coping with stress. This concurs with Schwarzer and Hallum's (2008) findings in their cross-legged panel research design that low self-efficacy is an antecedent of burnout. The results were also corroborated by several studies of different researchers across time. Brouwers and Tomic (2000), Schwarzer and Hallum (2008) and Skaalvik and Skaalvik (2007) were united in their results wherein they argued that burnout and self-efficacy are inversely related to one another. In order to improve their classroom selfefficacy, teachers' burnout has to be reduced. Strain relative to job stress results to burn-out and a low level of efficacy. Given the demands of the teaching profession, this will hit those who lack appropriate coping resources. 


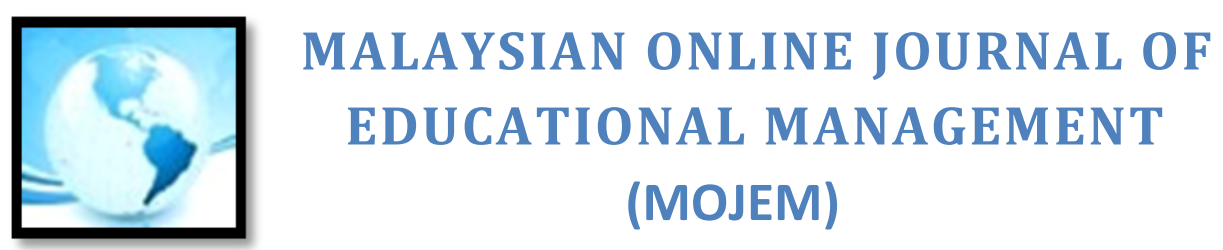

Eslami and Fatahi (2008) further suggest that school administrators should develop intervention programs to maintain or enhance teachers' sense of efficacy.

\section{Level of Organizational Commitment of Teachers}

The level of organizational commitment of teachers was shown in Table 6 with an overall mean of 4.00 or high and a standard deviation of 0.563 . Among the four indicators, moral imperative dimension obtained the highest mean of 4.23 or very high followed by affective commitment, 4.09 or high then indebted obligation dimension, 3.86 or high and continuance commitment with a mean of 3.84 or high.

Table 6

Level of Organizational Commitment of Teachers

\begin{tabular}{llll}
\hline Items & SD & Mean & Descriptive level \\
\hline $\begin{array}{l}\text { Affective Commitment } \\
\text { Continuance }\end{array}$ & 0.576 & 4.09 & High \\
$\begin{array}{l}\text { Commitment } \\
\text { Indebted Obligation }\end{array}$ & 0.761 & 3.84 & High \\
Dimension & 0.704 & & High \\
Moral Imperative & 0.611 & 3.86 & Very High \\
Dimension & & 4.23 & High \\
\multicolumn{1}{l}{ Overall } & 0.563 & &
\end{tabular}

A high level of organizational commitment is vital to any organization. This is backed up by Dixit and Bhati (2012), Murthy (2014), and Ulrich and Smallwood (2003) whose studies significantly predicted organization commitment. Furthermore, findings revealed that organizational commitment enhances organizational productivity due to increased motivation and performance of employees, increasing employee self-efficacy. The workforce's organizational commitment brings life to organizations, making it competitive, overcoming challenges head on (Choi \& Lee, 2011; Jehanzeb et al., 2013; Nicholson, 2009). For Shahzad, Rehman and Abbas (2010) and Johnson, Chang, and Yang (2010), organizational commitment is considered as one of the essential factors promoting the individual employee's ties with the organization.

\section{Correlation between Identity Orientation and Organizational Commitment}

The correlation between identity orientation and organizational commitment of public school teachers with an overall $r$-value of 0.494 at $p<0.01$ was shown in Table 6 . Since the $p$-value was less than 0.05 , there was a significant relationship between identity orientation and organizational commitment.

When one considers the measured-latent relationships, collective identity orientation had the highest value for a significant relationship with organizational commitment as it had the highest correlation coefficient of 0.460 . The social, relational, and personal identity orientations, on the other hand, obtained R-values of .419, 0.360 and .349 respectively, with all $p$-values less than 0.05 . This implied that all the measured variables of identity orientation had significant relationships with the measured variables of latent organizational commitment.

Similarly, all indicators of organizational commitment, correlated singularly with all indicators of identity orientation, showed significant relationships with one another. Affective commitment revealed the highest correlation coefficient of 0.475 . 


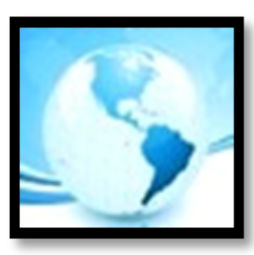

MALAYSIAN ONLINE JOURNAL OF

EDUCATIONAL MANAGEMENT

(MOJEM)

Table 7

Significance on the Relationship between Levels of Identity Orientation and Organizational Commitment

\begin{tabular}{|c|c|c|c|c|c|}
\hline & & Organizational & Commitment & & \\
\hline Identity & Affective & Continuance & Indebted & Moral & Overall \\
\hline Orientation & Commitment & Commitment & Obligation & Imperative & Organizational \\
\hline & $r$ value $p$ & $r$ value $p$ & Dimension & Dimension & Commitment \\
\hline & value & value & r value $p$ & $r$ value $p$ & rvalue $p$ \\
\hline Personal & & & value & value & value \\
\hline Identity & $0.341 * 0.000$ & $0.270 * 0.000$ & & & \\
\hline Orientation & & & $0.301 * 0.000$ & $0.279 * 0.000$ & \\
\hline Relational & $0.346 * 0.000$ & $0.284 * 0.000$ & & & $0.349 * 0.000$ \\
\hline Identity & & & $0.337 * 0.000$ & $0.259 * 0.000$ & \\
\hline Orientation & $0.406 * 0.000$ & $0.379 * 0.000$ & & & \\
\hline Social & & & $0.371 * 0.000$ & $0.260 * 0.000$ & \\
\hline Identity & $0.436 * 0.000$ & $0.426 * 0.000$ & & & $0.360 * 0.000$ \\
\hline Orientation & & & $0.379 * 0.000$ & $0.317 * 0.000$ & \\
\hline Collective & $0.475 * 0.000$ & $0.427 * 0.000$ & & & \\
\hline Identity & & & $0.431 * 0.000$ & $0.342 * 0.000$ & \\
\hline Orientation & & & & & $0.419 * 0.000$ \\
\hline \multirow{3}{*}{\multicolumn{6}{|c|}{$\begin{array}{l}\text { Overall } \\
\text { Identity } \\
\text { Orientation }\end{array}$}} \\
\hline & & & & & \\
\hline & & & & & \\
\hline & & & & & $0.460 * 0.000$ \\
\hline & & & & & $0.494 * 0.000$ \\
\hline
\end{tabular}

*Significant at 0.05 significance level.

The relationship between identity orientation and organizational commitment is described by Gonzales (2001) as identity having a vital role in employees' organizational commitment. Research data showed significant influence of personal and social identity orientations on organizational commitment. These organizational characteristics significantly influenced the relationship between identity and organizational commitment. This relationship supports Brickson (2007) who contends that identity orientation at an organizational level has a relationship with citizenship performance behaviour that enhances organizational commitment.

\section{Correlation between Immediacy Behaviour and Organizational Commitment}

Table 8 shows the relationship between immediacy behaviour and organizational commitment. Considering the latent-latent relationships, data indicated that the $r$-value and $p$-values indicate a positive relationship towards each variable. The findings further showed that the two observed indicators of immediacy behaviour had probability values of $p<0.01$ towards latent organizational commitment. It can be observed that verbal behaviour got a higher correlation than nonverbal behaviour with organizational commitment as shown in their R-values of 0.465 and 0.418 , respectively. This meant that the measured variables of latent immediacy behaviour had a distinct positive connection with potential organizational commitment.

On the other hand, affective commitment got the highest correlation with immediacy behaviour with an $r$ value of 0.504. Continuance commitment, indebted obligation dimension, and moral imperative dimensions obtained $r$ values of $0.460,0.460$, and 0.318 , respectively.

Immediacy behaviour is based on the Implicit Communication Theory of Mehrabian (1981) that messages are sent using two types of communication, explicit and implicit. The former is called verbal communication, and the 


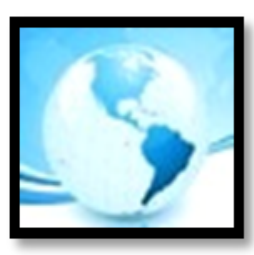

latter is nonverbal communication. The findings of Allen (1992) showed that superior-subordinate communication was strongly related to organizational commitment. In this case, quality student-teacher communication promotes commitment.

Table 8

Significance on the Relationship between Levels of Immediacy Behaviour and Organizational Commitment

\begin{tabular}{|c|c|c|c|c|c|}
\hline & & Organizational & Commitment & & \\
\hline Immediacy & Affective & Continuance & Indebted & Moral & Overall \\
\hline Behaviour of & Commitment & Commitment & Obligation & Imperative & Organizational \\
\hline Teachers & $r$ value $p$ & $r$ value $p$ & Dimension & Dimension & Commitment \\
\hline & value & value & $\begin{array}{r}\text { rvalue } p \\
\text { value }\end{array}$ & $\begin{array}{r}\text { rvalue } p \\
\text { value }\end{array}$ & $\begin{array}{l}\text { r value } p \\
\text { value }\end{array}$ \\
\hline Verbal items & $0.456 * 0.000$ & $0.394 * 0.000$ & $0.396 * 0.000$ & $0.355 * 0.000$ & $0.465 * 0.000$ \\
\hline $\begin{array}{l}\text { Nonverbal } \\
\text { items }\end{array}$ & $0.409 * 0.000$ & $0.392 * 0.000$ & $0.390 * 0.000$ & $0.218 * 0.000$ & $0.418 * 0.000$ \\
\hline $\begin{array}{l}\text { Overall } \\
\text { Immediacy }\end{array}$ & $0.504 * 0.000$ & $0.460 * 0.000$ & $0.460 * 0.000$ & $0.318 * 0.000$ & $0.515 * 0.000$ \\
\hline Behaviour & & & & & \\
\hline
\end{tabular}

*Significant at 0.05 significance level.

\section{Correlation between Teacher Self-Efficacy and Organizational Commitment}

In Table 9, it is shown that the relationship between teacher self-efficacy and organizational commitment with an overall $r$-value of 0.431 . When one considers the latent-latent relationships, data indicated that the $r$-value and $p$ values had a positive relationship towards each variable. The findings further showed that the four observed variables of teacher self-efficacy had a probability value of $p<0.01$ towards the latent OC. It was observed that coping with stress got the highest correlation followed by social interaction with students, parents, and colleagues, kinesthetics, job accomplishment, and skill development on the job as reflected in their r-values of $0.431,0.372$, 0.341 and 0.266 , respectively. This meant that the measured variables of latent teacher self-efficacy had a distinct positive connection towards the latent OC.

Table 9

Significance on the Relationship between Levels of Teacher Self-efficacy and Organizational Commitment

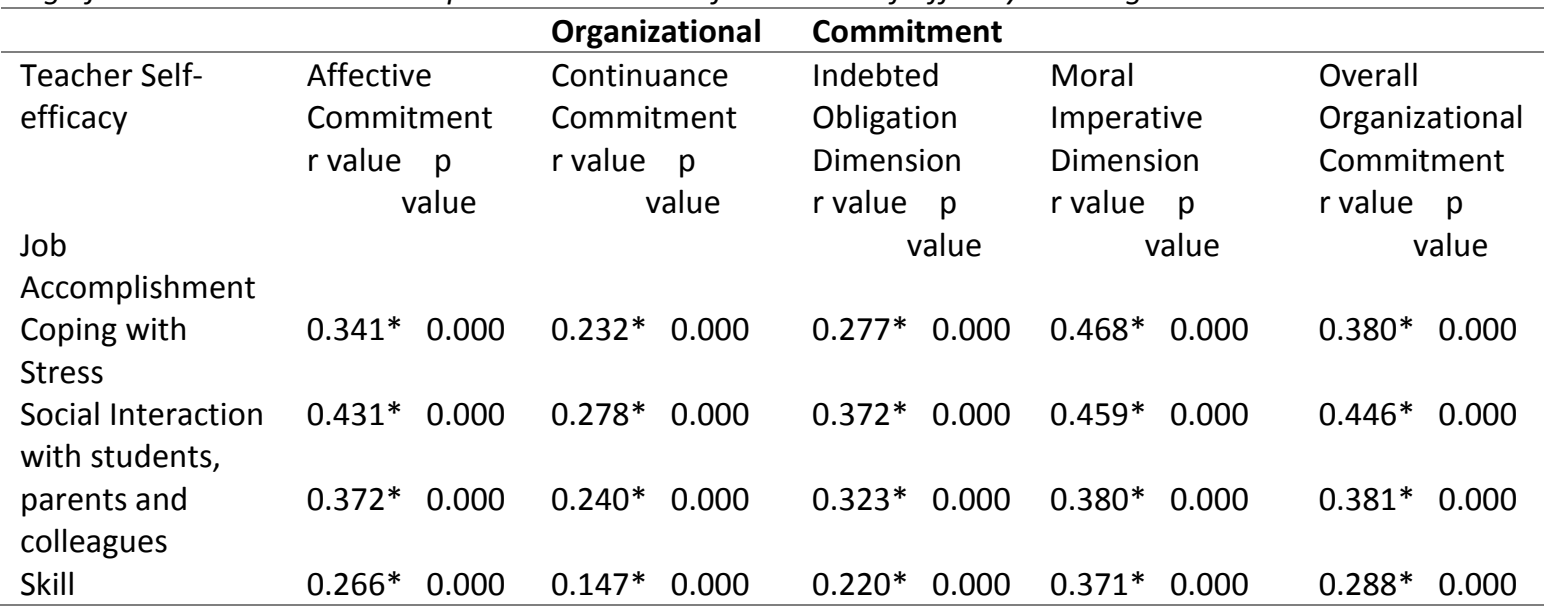




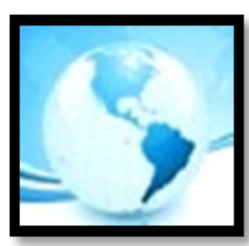

MALAYSIAN ONLINE JOURNAL OF

EDUCATIONAL MANAGEMENT

(MOJEM)

Development on

the job

$0.407 * 0.000 \quad 0.258 * 0.000$

$0.344 * 0.000 \quad 0.484 * 0.000$

$0.431 * 0.000$

Overall Teacher

Self-Efficacy

*Significant at 0.05 significance level

Similarly, the data revealed that the observed variables of OC all had probability values of $p<0.01$ towards latent teacher self-efficacy. The moral imperative dimension received the highest $r$ value of 0.484 followed by affective commitment, indebted obligation dimension, and continuance commitment with $r$ values of $0.407,0344$, and 0.258 , respectively. All $p$ values were less than 0.05 .

The teachers' beliefs in their ability to perform effectively as teachers are enhanced through their improved teaching skills. This idea resounds with Detary (2003) wherein a positive relationship was revealed between efficacy and organizational commitment. Furthermore, the same study showed a positive correlation between selfefficacy and employee commitment. This contention is highlighted in the study by Tschannen-Moran and Hoy (2001) who revealed that uncommitted employees showed a lower level of self-efficacy. Dibapile (2012), Mojavezi and Tamiz (2012), Pan (2014) and Richardson (2011) agreed that some educational outcomes related to teacher efficacy such as teachers' persistence, enthusiasm, commitment are also related to student motivation which brings about high student achievement.

\section{Regression Analysis on the Extent of Influence of the Predictor Variables on Organizational Commitment}

Table 10 shows the regression analysis test results which showed the significant predictors of organizational commitment concerning the observed variables of the study. The $F$ value of 133.16 with a corresponding $p<0.01$ indicated that the regression model was significant, thus the rejection of the null hypothesis. This implied that the predictor variables identity orientation, immediacy behaviour, and teacher self-efficacy had a direct influence on the organizational commitment of teachers.

Table 10

The extent of Influence of Predictor Variables on Organizational Commitment

\begin{tabular}{|c|c|c|c|c|}
\hline $\begin{array}{l}\text { Independent } \\
\text { variables }\end{array}$ & $\begin{array}{l}\text { Organizational } \\
\text { B (Standardized } \\
\text { Coefficients }\end{array}$ & $\begin{array}{l}\text { Commitment } \\
\text { B } \\
\text { (Unstandardized } \\
\text { Coefficients) }\end{array}$ & $\begin{array}{l}\text { (Dependent } \\
\text { Variable) } \\
\text { T }\end{array}$ & Sig. \\
\hline Constant & 0.2077 & 0.1911 & 1.09 & 0.278 \\
\hline $\begin{array}{l}\text { Identity } \\
\text { Orientation (IO) } \\
\text { Immediacy }\end{array}$ & 0.27937 & 0.05529 & 5.05 & 0.000 \\
\hline $\begin{array}{l}\text { Behaviour of } \\
\text { Teachers (IV) }\end{array}$ & 0.41009 & 0.05492 & 7.47 & 0.000 \\
\hline $\begin{array}{l}\text { Teacher Self- } \\
\text { efficacy (TE) }\end{array}$ & $\begin{array}{l}0.25111 \\
0.409\end{array}$ & 0.04232 & 5.93 & 0.000 \\
\hline $\mathrm{R}$ & 0.640 & & & \\
\hline $\mathrm{R}^{2}$ & 133.16 & & & \\
\hline$p$ & 0.000 & & & \\
\hline
\end{tabular}




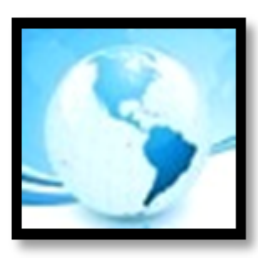

\section{MALAYSIAN ONLINE JOURNAL OF EDUCATIONAL MANAGEMENT (MOJEM)}

Moreover, all the independent variables had significant influences on organizational behaviour as all their individual $p$ values were less than 0.05. Further analysis showed that the standard coefficient of immediacy behaviour of teachers had the highest Beta value of 0.410 . This illustrated that immediacy behaviour had a higher influence compared to identity orientation and teacher self-efficacy with beta values of 0.279 and 0.251 , respectively. The $\mathrm{R}^{2}$ value of 0.640 implied that $64.0 \%$ of the variance of the organizational commitment is explained by the independent variables in the model while $36.0 \%$ of the variations of organizational commitment are attributed to other factors.

From the analysis, the regression model for organizational commitment of teachers is:

$Y^{\prime}=0.208+0.279 X_{1}+0.410 X_{2}+0.251 X_{3}$

Where:

$Y^{\prime}=$ the level of organizational commitment $(O C)$

$\mathrm{X}_{1}=$ Identity Orientation (IO)

$\mathrm{X}_{2}=$ Immediacy Behaviour (IV)

$X_{3}=$ Teacher Self-Efficacy (TE)

The results concur with the researches by Brophy (2004), Butland and Beebe (1992), Daughtry, Spagnola and Boyles (2014) and Rodriguez et al. (1996). Their results showed that teacher immediacy increases student motivation to learn and improves students liking the teacher as well as the subject. This would then decreases the students' anxiety to participate in class activities, thereby increasing their perception of teacher effectiveness which in turn promotes teacher self-efficacy and predicts employee commitment.

\section{Structural Model Testing}

Based on the literature and theories, the interrelationship among the variables of the study: identity orientation, immediacy behaviour, and teacher self-efficacy were considered critical variables to influence organizational commitment. Hence, structural models were developed to investigate their correspondence. Model 1 was tested and found to be deficient while several alternative models were also tested in an attempt to achieve the best fit model. A discussion of the models and their implications for understanding the influence of the exogenous variables on endogenous variables was also carried out.

\section{Test of Hypothesized Model 1}

Hypothesized Model 1 is depicted as the causal relationships of Identity orientation, immediacy behaviour, and teacher self-efficacy towards the organizational commitment of teachers.

As reflected in Table 11, the goodness of fit of Model 1 was examined using the following indices: Chisquare/Degrees of Freedom (CMIN/DF), Root Mean Square of Error Approximation (RMSEA), Normed Fit Index (NFI), Tucker-Lewis Index (TLI), Comparative Fit Index (CFI), and Goodness of Fit Index (GFI). The criterion for each index that indicates a good fit is also shown in Table 10. The results indicated a poor fit of the model to the data as reflected by CMIN/DF = 6.294. Depicted in Figure 6 is Structural Model 1 regarding standardized solutions. 


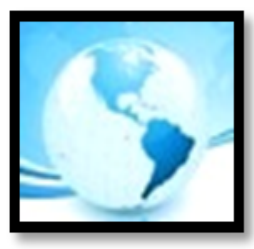

MALAYSIAN ONLINE JOURNAL OF

EDUCATIONAL MANAGEMENT

(MOJEM)

Table 11

Goodness of Fit Measures of Structural Model 1

\begin{tabular}{|c|c|c|}
\hline Index & Criterion & Model Fit Value \\
\hline \multirow[t]{2}{*}{ P-Close } & $>0.05$ & 0.000 \\
\hline & & 6.294 \\
\hline CMIN/DF & $0<$ value $<2$ & 0.899 \\
\hline GFI & $>0.95$ & 0.917 \\
\hline \multirow[t]{2}{*}{ CFI } & $>0.95$ & 0.903 \\
\hline & & 0.890 \\
\hline $\mathrm{NFI}$ & $>0.95$ & 0.096 \\
\hline TLI & $>0.95$ & \\
\hline RMSEA & $<0.05$ & \\
\hline
\end{tabular}

Legend:

$\begin{array}{lll}\text { CMIN/DF } & - & \text { Chi-Square/Degrees of Freedom } \\ \text { NFI } & - & \text { Normed Fit Index } \\ \text { TLI } & - & \text { Tucker-Lewis Index } \\ \text { CFI } & - & \text { Comparative Fit Index } \\ \text { GFI } & - & \text { Goodness of Fit Index }\end{array}$

RMSEA - Root Means Square of Error Approximation

Pclose - P of Close Fit

with its $\mathrm{p}$-value $=.000, \mathrm{NFI}=.903, \mathrm{TLI}=.890, \mathrm{CFI}=.917, \mathrm{GFI}=.899, \mathrm{RMSEA}=.096$

with Pclose $x$

COLLECT - Collective AFFECT - Affective Dimension

.000 , all of which do not fall within each criterion. 


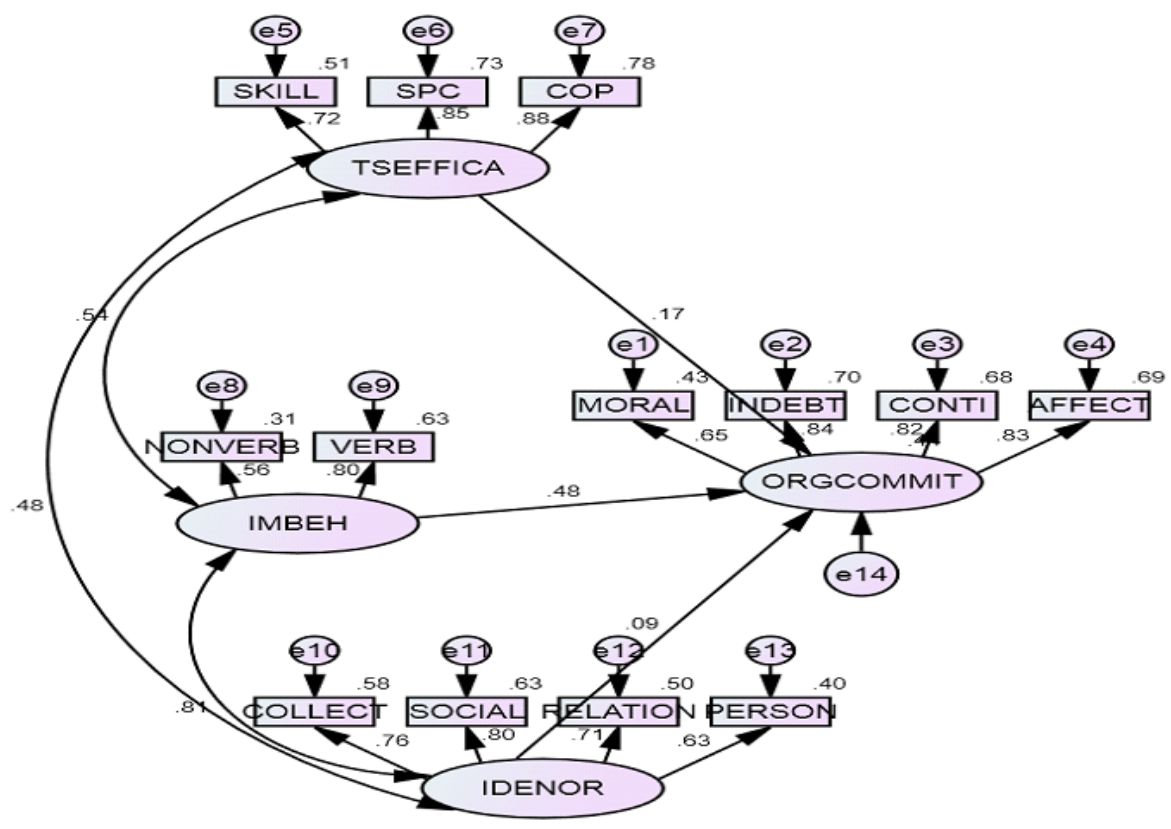

Figure 6. Structural Model 1 in Standardized Solution

TSEFFICA: Teacher Self-Efficacy; SKILL: Skill Development on the Job; SPC: Social Interactions with Parents and Colleagues; COP: Coping with Stress; IMBEH; Immediacy Behaviour; NONVERB: Nonverbal; VERB: Verbal; ORGCOMMIT: Organizational Commitment; MORAL: Moral Imperative Dimension; INDEBT: Indebted Obligation Dimension; CONTI: Continuance; AFFECT: Affective; IDENOR : Identity Orientation; COLLECT: Collective; SOCIAL: Social; RELATION: Relational; PERSON: Personal

\section{Test of Hypothesized Model}

Table 12 presented the Goodness of fit measures for Model 2. Similar to the Hypothesized Model 1, the results revealed that the fit indices were all not within the acceptable range, indicating a poor data fit of the model. The results is as reflected by CMIN/DF $=6.770, \mathrm{GF} !=0.912, \mathrm{CFI}=0.926, \mathrm{NFI}=0.915, \mathrm{TLI}=0.901, \mathrm{RMSEA}=0.100$, and $\mathrm{P}$ Close $=0.000$, showed that all do not fall within each criterion. Depicted in Figure 7 is Structural Model 2 regarding the standardized solutions. 


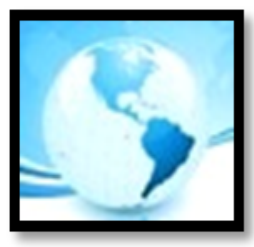

MALAYSIAN ONLINE JOURNAL OF

EDUCATIONAL MANAGEMENT

(MOJEM)

Table 12

Goodness of Fit Measures of Structural Model 2

\begin{tabular}{ccc}
\hline Index & Criterion & Model Fit Value \\
\hline P-Close & $>0.05$ & \\
CMIN/DF & $0<$ value $<2$ & 0.000 \\
GFI & $>0.95$ & 6.770 \\
CFI & $>0.95$ & 0.912 \\
NFI & $>0.95$ & 0.926 \\
TLI & $>0.95$ & 0.915 \\
RMSEA & $<0.05$ & 0.901 \\
L & & 0.100
\end{tabular}

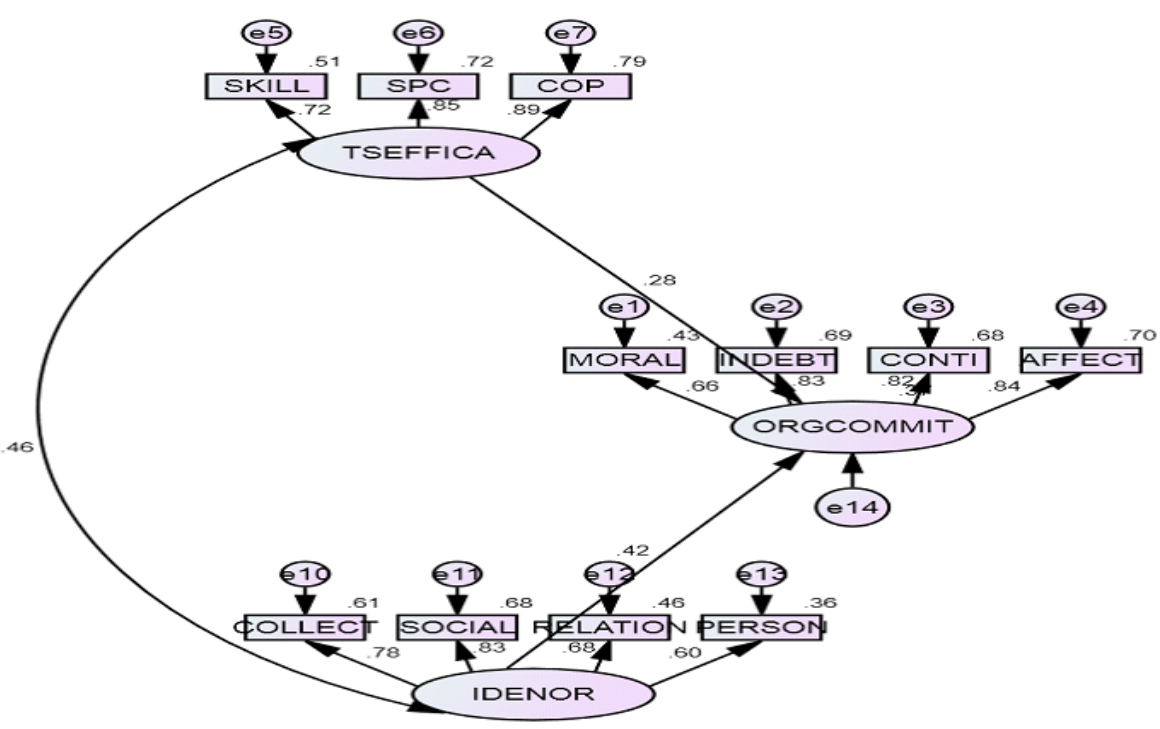

Figure 7. Structural Model 2 in Standardized Solution

TSEFFICA: Teacher Self-Efficacy; SKILL: Skill Development on the Job; SPC: Social Interactions with Parents and Colleagues; COP: Coping with Stress; ORGCOMMIT: Organizational Commitment; MORAL: Moral Imperative Dimension; INDEBT: Indebted Obligation Dimension; CONTI: Continuance; AFFECT: Affective; IDENOR: Identity Orientation; COLLECT: Collective; SOCIAL : Social; RELATION: Relational; PERSON: Personal 


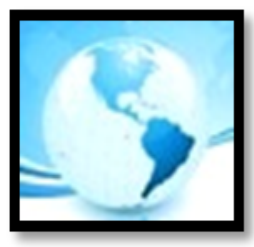

\section{Test of Hypothesized Model 3}

Table 13 presented the goodness of fit measures for Model 3. Similar to the Hypothesized Model 2, the results revealed that the fit indices were all not within the acceptable range, indicating a poor data fit of the model. The results as reflected by $\mathrm{CMIN} / \mathrm{DF}=7.202, \mathrm{GFI}=0.920, \mathrm{CFI}=0.925, \mathrm{NFI}=0.915, \mathrm{TLI}=0.895, \mathrm{RMSEA}=0.104$, and $\mathrm{P}$ Close $=0.000$, do not fall within each criterion. Depicted in Figure 8 is the Structural Model 3 regarding standardized solutions.

Table 13

Goodness of Fit Measures of Structural Model 3

\begin{tabular}{ccc}
\hline Index & Criterion & Model Fit Value \\
\hline P-Close & $>0.05$ & \\
CMIN/DF & $0<$ value $<2$ & 0.000 \\
GFI & $>0.95$ & 7.202 \\
CFI & $>0.95$ & 0.920 \\
NFI & $>0.95$ & 0.925 \\
TLI & $>0.95$ & 0.915 \\
RMSEA & $<0.05$ & 0.895 \\
& & 0.104 \\
\hline
\end{tabular}




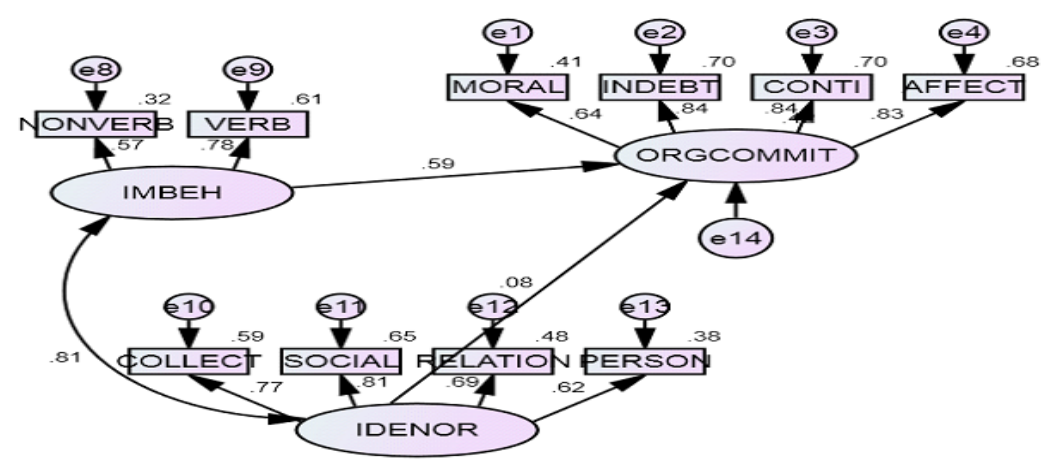

Figure 8. Structural Model 3 in Standardized Solution

IMBEH: Immediacy Behaviour; NONVERB: Nonverbal; VERB: Verbal; ORGCOMMIT: Organizational Commitment; MORAL: Moral Imperative Dimension; INDEBT: Indebted Obligation Dimension; CONTI: Continuance; AFFECT: Affective; IDENOR: Identity Orientation; COLLECT: Collective; SOCIAL : Social; RELATION: Relational; PERSON: Personal

\section{Test of Hypothesized Model 4}

Presented in Table 14 is the goodness of fit measures for Model 4. Similar to the Hypothesized Model 3, the results revealed that the fit indices were all not within the acceptable range, indicating a poor data fit of the model. The results as reflected by $\mathrm{CMIN} / \mathrm{DF}=6.709, \mathrm{GFI}=0.937, \mathrm{CFI}=0.945, \mathrm{NFI}=0.937, \mathrm{TLI}=0.918, \mathrm{RMSEA}=0.100$, and $\mathrm{P}$ Close $=0.000$, do not fall within each criterion. Depicted in Figure 9 is the Structural Model 4 regarding standardized solutions.

Table 14

Goodness of Fit Measures of Structural Model 4

\begin{tabular}{cll}
\hline Index & Criterion & Model Fit Value \\
\hline P-Close & $>0.05$ & 0.000 \\
CMIN/DF & $0<$ value $<2$ & 6.709 \\
GFI & $>0.95$ & 0.937 \\
CFI & $>0.95$ & 0.945 \\
NFI & $>0.95$ & 0.937 \\
TLI & $>0.95$ & 0.918 \\
RMSEA & $<0.05$ & 0.100 \\
\hline
\end{tabular}




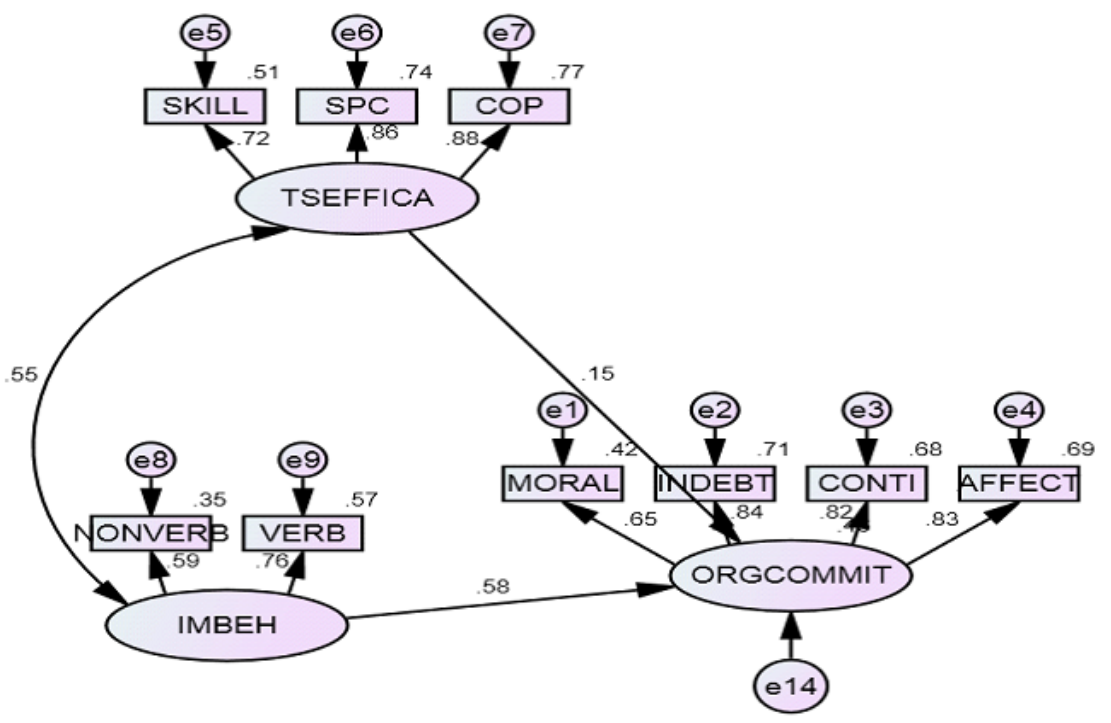

Figure 9. Structural Model 4 in Standardized Solution

TSEFFICA: Teacher Self-Efficacy; SKILL: Skill Development on the Job; SPC: Social Interactions with Parents and Colleagues; COP: Coping with Stress; IMBEH: Immediacy Behaviour; NONVERB: Nonverbal; VERB: Verbal; ORGCOMMIT: Organizational Commitment; MORAL: Moral Imperative Dimension; INDEBT: Indebted Obligation Dimensi on; CONTI: Continuance; AFFECT: Affective

\section{Test of Hypothesized Model 5}

Table 15 presented the goodness of fit measures for Model 5. Similar to Hypothesized Model 3, the results revealed that the fit indices were all within the acceptable range indicating the best data fit of the model. The results were: $\mathrm{CMIN} / \mathrm{DF}=1.007, \mathrm{GFI}=0.997, \mathrm{CFI}=1.000, \mathrm{NFI}=0.995, \mathrm{TLI}=1.000, \mathrm{RMSEA}=0.003$, and $\mathrm{P}-\mathrm{Close}=$ 


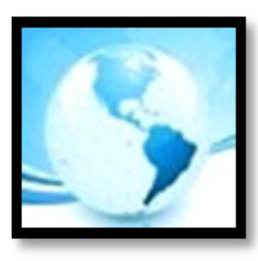

\section{MALAYSIAN ONLINE JOURNAL OF EDUCATIONAL MANAGEMENT (MOJEM)}

0.419, and these show that all fall within each criterion. Depicted in Figure 10 is Structural Model 5 regarding standardized solutions.

Model 5 depicted the correlation of IMBEH and IDENOR and its direct causal relation towards ORGCOMMIT. As observed, some measured variables are reasonably removed to meet the criterion of goodness of fit. Part of model modification is trimming through the elimination of the measured and even latent variables that do not directly contribute to the fitness of model. The reasons could be caused by poor or weak influence and/or the uniformity of the responses that makes prevailing findings universal/common fact.

The influence between the latent variables and between the measured and latent variables are projected to exhibit regression weights as shown in the model. The results showed that all the paths in the model were significant since the $p$-values were less than .05 . This meant that identity orientation and immediacy behaviour of teachers significantly predicted their organizational commitment.

Model 5 demonstrated the standardized solution. Results indicated that the combined influence of IMBEH and IDENOR explained the 47.1 percent variation of ORGCOMMIT, which is higher than the 4.7 percent from Model 3. Similarly, considering the latent-latent relationships, IMBEH was considered to have the highest influence (beta 0.58) while IDENOR's beta of 0.13 indicated negligible influence towards ORCOMMIT. However, as shown in the figure, IDENOR's correlation r-value of 0.74 signified a high correlation towards IMBEH.

When the latent-measured variable relationships is considered, the following results were inferred from the model: It could be shown in the $\mathrm{R}^{2}$ values of these observed variables that 73 percent of IDENOR could be explained by the measured COLLECT compared to SOCIAL (67\%). The observed variable VERB (54\%) explained greater variation on IMBEH compared to NONVERB (36\%). Likewise, the measured variables AFFECT (71\%) CONTI (67\%) also indicated a substantial impact to explain ORGCOMMIT.

Table 15

Goodness of Fit Measures of Structural Model 5

\begin{tabular}{ccc}
\hline Index & Criterion & Model Fit Value \\
\hline P-Close & $>0.05$ & 0.419 \\
CMIN/DF & $0<$ value $<2$ & 1.007 \\
GFI & $>0.95$ & 0.997 \\
CFI & $>0.95$ & 1.000 \\
NFI & $>0.95$ & 0.995 \\
TLI & $>0.95$ & 1.000 \\
RMSEA & $<0.05$ & 0.003 \\
\hline
\end{tabular}




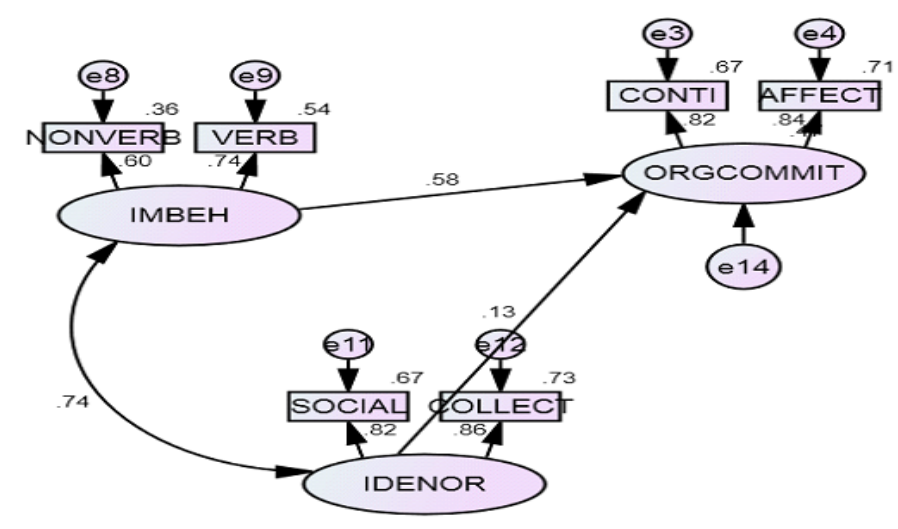

Figure 10. Structural Model 5 in Standardized Solution

IMBEH: Immediacy Behavi our; NONVERB: Nonverbal; VERB: Verbal; ORGCOMMIT: Organizational Commitment; CONTI: Continuance; AFFECT: Affective; IDENOR: Identity Orientation; SOCLAL; Social; COLLECT: Collective

\section{Summary of the Fitness Testing of Hypothesized Models}

In order to address the research question on the identification of the best fit model, the original proposed model outlined in Figure 1 needed some modifications to fit the data. There were five structural models presented in this study and the summary of the goodness of fit measures of these structural models is as reflected in Table 16.

In identifying the best fit model, all the indices included must fall within acceptable ranges. Chi-Square / Degrees of Freedom (CMIN/DF) should be between 0 and 2, with its corresponding p-value greater than 0.05. Root Mean Square of Error Approximation (RMSEA) value must be less than 0.05 with its Pclose value also greater than 0.05 . The other indices such as Normed Fit Index (NFI), Tucker-Lewis Index (TLI), Comparative Fit Index (CFI), and Goodness of Fit Index (GFI) must be greater than 0.95 .

Model 1 only considers the direct causal relationship of identity orientation, immediacy behaviour, and teacher self-efficacy toward Organizational Commitment of teachers. As obtained, the model yielded the following fit index values: $\mathrm{CMIN} / \mathrm{DF}=6.294$ with its $\mathrm{p}$-value $=.000, \mathrm{NFI}=0.903, \mathrm{TLI}=0.890, \mathrm{CFI}=0.917, \mathrm{GFI}=0.899, \mathrm{RMSEA}=0.096$ with Pclose $=0.000$, all of which do not fall within the respective criterion. This indicates a poor fit of the data to the model. 


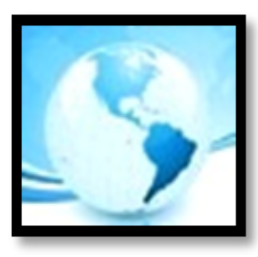

As a result of the poor fit of Model 2, it was decided that SEM analysis should be done separately for teacher selfefficacy and identity orientation towards organizational commitment. This model considered the correlation between teacher self-efficacy and identity orientation and their direct causal relationships to the organizational commitment of teachers. The model was found to be non-fitting to the data as indicated by CMIN/DF $=6.770$ with its $\mathrm{p}$-value $=.000, \mathrm{NFI}=0.915, \mathrm{TLI}=0.901, \mathrm{CFI}=0.926, \mathrm{GFI}=0.912, \mathrm{RMSEA}=0.100$ with Pclose $=0.000$, all of which did not fall within the acceptable range of the respective criterion.

Table 16

Summary of Goodness of Fit Measures of the Five Structural Models

$\begin{array}{ccccccccc}\text { Model } & \text { CMIN/DF } & \text { P-Value } & \text { NFI } & \text { TLI } & \text { CFI } & \text { GFI } & \text { RMSEA } & \text { P-Close } \\ & 0<\text { value }>2 & >.05 & >.95 & >.95 & >.95 & >.95 & <.05 & >.05\end{array}$

\begin{tabular}{lllllllll}
\hline 1 & 6.294 & 0.000 & 0.903 & 0.890 & 0.917 & 0.899 & 0.096 & 0.000 \\
2 & 6.770 & 0.000 & 0.915 & 0.901 & 0.926 & 0.912 & 0.100 & 0.000 \\
3 & 7.202 & 0.000 & 0.915 & 0.895 & 0.925 & 0.920 & 0.104 & 0.000 \\
4 & 6.709 & 0.000 & 0.937 & 0.918 & 0.945 & 0.937 & 0.100 & 0.000 \\
5 & 1.007 & 0.419 & 0.995 & 1.000 & 1.000 & 0.997 & 0.003 & 0.924 \\
\hline
\end{tabular}

Likewise, as a result of having a poor fit of Model 3, it was decided that there some modifications were needed. Therefore, it was done by doing the SEM analysis separately for teacher immediacy behaviour and identity orientation towards organizational commitment. The third hypothesized structural model showed the correlation between immediacy behaviour and identity orientation and its direct causal relationship to organizational commitment. The results revealed the following: $\mathrm{CMIN} / \mathrm{DF}=7.202$ with its $p$-value $=.000, \mathrm{NFI}=0.915, \mathrm{TLI}=0.895$, $\mathrm{CFI}=0.925, \mathrm{GFI}=0.920, \mathrm{RMSEA}=0.104$ with Pclose $=0.000$, all of which did not fall within the acceptable range of the respective criterion. This implied that Model 3 still did not fit to the data.

Similarly, as a result of having a poor fit of Model 4, SEM analysis was done separately for the correlation between teacher self-efficacy and immediacy behaviour and its direct causal relationship to organizational commitment. The values of the fit indices such as NFI, TLI, CFI, and GFI were 0.937, 0.918, 0.945, and 0.937, respectively while CMIN/DF (P-value $=0.000$ ) and RMSEA values were 6.709 and 0.100 , respectively with P-Close of 0.000 . These results indicate a poor fit of the model to the data.

Finally, the fifth structural model (final model) portrayed a modification of Model 3 retaining only the two subconstructs with the highest beta values of identity orientation, namely: SOCIAL $($ Beta $=0.81)$ and COLLECT (Beta = $0.77)$ while retaining two sub-constructs of organizational commitment, AFFECT $($ Beta $=0.83)$ and CONTI $($ Beta $=$ 0.84). Model 5 considered the correlation between immediacy behaviour and identity orientation and its direct causal relationship to organizational commitment. As shown in Table 15, Model 5 fits well with the data required in each criterion and therefore serves as the best fit model of organizational commitment of teachers.

The model portrays the importance of immediacy behaviour and identity orientation with its two constructs-social and collective identity orientation as a significant predictor of organizational commitment described by affective and continuance teacher commitment. Thus, the finding suggests that organizational commitment of teachers is best anchored in the immediacy behaviour of teachers and identity orientation as supported by the two subconstructs: social and collective orientation.

This model finds strong support in Brickson (2007) who pointed out that identity orientation at an organizational level has a relationship with citizenship performance behaviour that enhances organizational commitment. 


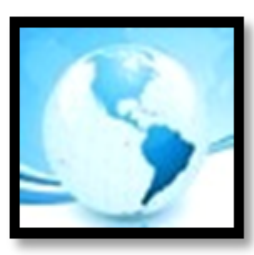

\section{MALAYSIAN ONLINE JOURNAL OF EDUCATIONAL MANAGEMENT (MOJEM)}

Furthermore, Gonzales (2001) described the role of identity in employees' organizational commitment. Research showed that there was a significant influence on personal and social identity orientations on organizational commitment. Organizational characteristics significantly influenced the relationship between identity and organizational commitment. According to Thoits (2003), collective identities strengthened role identities in joint undertakings that boost individual self-efficacy, self- esteem, and self-affirmation or authenticity. Moreover, Garcia (2015) stated that there is a direct link between identity orientation with efficacy which in turn has a direct connection with organizational commitment. On the other hand, teacher immediacy increases student motivation to learn and improves students liking the teacher as well as the subject and decreases anxiety to participate in class activities, thereby increasing student perception of teacher effectiveness, enhancing teacher self-efficacy which in turn predicts organizational commitment.

\section{IMPLICATIONS}

A series of immediacy behaviour and identity orientation training and seminars anchored on the best fit model on organizational commitment may be conducted by the country's education officials. Teaching programs designed to bridge educational gaps addressing the needs of teachers specifically on the identified teachers' strengths and requirements must also be developed.

School heads may further enhance teachers' immediacy behaviour through programs and activities that may hone their verbal and nonverbal communication skills inside classrooms. Furthermore, they may implement strategies and activities that further develop the teachers' social and collective identity orientation to enhance their public self-consciousness, sociability, and institutional and altruistic selves. By being able to identify these identities, school heads could easily handle and manage the teachers.

Teachers may also engage in or attend training and seminar-workshops that enrich and improve their commitment based on the constructs of identity orientation and immediacy behaviour of the best fit model.

\section{CONCLUSION}

There is a high level of identity orientation among public school teachers in the nine divisions of Region XI with a very high level of relational identity orientation; a high level of immediacy behaviour of teachers; a very high level of teacher self-efficacy; and high level of organizational commitment.

The identity orientation, immediacy behaviour, and self-efficacy of teachers positively correlate with their organizational commitment. Moreover, the combination of identity orientation, immediacy behaviour, and teacher self-efficacy significantly influenced the organizational commitment of teachers.

The Structural Model 5 is the best fit model. This indicates that the organizational commitment of teachers with two sub-constructs from the original four, continuance and affective, is best anchored on strong evidence of immediacy behaviour as supported by its two sub-constructs nonverbal and verbal immediacy behaviour and identity orientation with two specific sub-constructs, social and collective orientation.

Further studies may also be conducted to validate the results of the present study. Aside from that, it can also be conducted in order to explore other factors using other research methods to address the need to improve teachers' organizational commitment. 


\section{REFERENCES}

Allen, M. W. (1992). Communication and organizational commitment: Perceived organizational support as a mediating factor. Communication Quarterly, 40(4), 357-367.

Anttila, E. (2015). Components of organizational commitment-A case study consisting of managers from Finnish industrial company (Master's dissertation). Retrieved from http://tampub.uta.fi/handle/10024/96724

Bandura, A. (1986). The explanatory and predictive scope of self-efficacy theory. Journal of Social and Clinical Psychology, 4(3), 359-373.

Brickson, S. (2000). The impact of identity orientation on individual and organizational outcomes idemographically diverse settings. Academy of Management Review, 25(1), 82-101.

Brickson, S. L. (2007). Organizational identity orientation: The genesis of the role of the firm and distinct forms of social value. Academy of Management Review, 32(3), 864-888.

Brophy, J. (2004). Motivating students to learn (2nd ed.). New Jersey: Lawrence Erlbaum Associates.

Brouwers, A., \& Tomic, W. (2000). A longitudinal study of teacher burnout and perceived self-efficacy in classroom management. Teaching and Teacher Education, 16(2), 239-253.

Butland, M. J., \& Beebe, S. A. (1992). Teacher immediacy and power in the classroom: The application of implicit communication theory. Paper presented at the Annual Meeting of the International Communication Association, Miami, FL. Retrieved from https://files.eric.ed.gov/fulltext/ED371421.pdf

Caprara, G. V., Barbaranelli, C., Steca, P., \& Malone, P. S. (2006). Teachers' self-efficacy beliefs as determinants of job satisfaction and students' academic achievement: A study at the school level. Journal of School Psychology, 44(6), 473-490.

Cato, S. T., \& Gordon, J. (2012). Relationship of the strategic vision alignment to employee productivity and student enrolment. Research in Higher Education Journal, 15(1), 1-20. Retrieved from http://www.aabri.com/manuscripts/111057.pdf

Chavez, Jr., F. C. (2012). Organizational commitment as influenced by leadership behaviour of administrators, job satisfaction and burnout of teachers: A structural equation modeling. UIC Research Journal, 18(1), 131154. Retrieved from http://ejournals.ph/form/cite.php?id=2117

Cheek, J. M. (1989). Identity orientations and self-interpretation. In Personality

Psychology (pp. 275-285). New York: Springer. Retrieved from https://link.springer.com/chapter/10.1007/978-1-4684-0634-4_21

Cheek, J. M., \& Briggs, S. R. (2013). Aspects of Identity Questionnaire (AIQ-IV). Measurement instrument database for the social science. Retrieved from https://www.midss.org/sites/default/files/aiq.pdf

Chew, P. G. L. (2007, January). Identity and globalization: EIL in Korea and Singapore. Paper presented at the Asian Efl Journal Conference. Retrieved from https://www.sid.ir/En/Journal/ViewPaper.aspx?ID=321828

Choi, S. L., \& Lee, Y. T. (2011). Relationship between leadership style, job satisfaction and employees' turnover intention: A literature review. Research Journal of Business Management, 5(3), 91-100. 


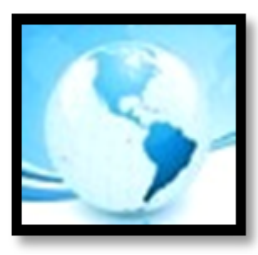

Cranton, P. (2001). Becoming an authentic teacher in higher education. Professional practices in adult education and human resource development series. Malabar, FL: Krieger Publishing Company.

Dabas, D., \& Pandey, N. (2015). Self-efficacy and optimism as a predicator of organizational commitment among academicians in private and public sector institutions. International Journal of Education and Management Studies, 5(1), 83-88. Retrieved from https://search.proquest.com/docview/1680664007?pq-origsite=gscholar

Dalanon, J., Diano, L. M., Belarmino, M. P., Hayama, R., Miyagi, M., \& Matsuka, Y. (2018). A Philippine rural school's organizational climate, teacher's performance and management competencies. Online Submission, 6(1), 248-265. Retrieved from https://files.eric.ed.gov/fulltext/ED581405.pdf

Daughtry, J. B., Spagnola, G., \& Boyles, G. (2014). A qualitative study of teacher immediacy and its effect upon student motivation (Unpublished doctoral dissertation). Argosy University, California.

Detary, T. (2003). The relationship between self-efficacy, optimism, and organizational commitment among registered nurses in a long-term milieu. (Unpublished doctoral dissertation). Argosy University, Sarasota. Retrieved from https://elibrary.ru/defaultx.asp?rpage=https://elibrary.ru/item.asp?id=8878778

Dibapile, W. T. S. (2012). A review of the literature on teacher efficacy and classroom management. Journal of College Teaching and Learning, Second Quarter, 9(2), 79-91. Retrieved from https://trace.tennessee.edu/cgi/viewcontent.cgi?article=1031\&context=utk_educpubs

Dixit, V., \& Bhati, M. (2012). A study about employee commitment and its impact on sustained productivity in Indian auto-component industry. European journal of Business and Social Sciences, 1(6), 34-51.

Eslami, Z. R., \& Fatahi, A. (2008). Teachers' sense of self-efficacy, English proficiency and instructional strategies: A study of non-native EFL teachers in Iran. Teaching English as a Second or Foreign Language (TESLEJ), 11(4), 1-19. Retrieved from https://files.eric.ed.gov/fulltext/EJ898136.pdf

Fornes, S. L., Rocco, T. S., \& Wollard, K. K. (2008). Workplace commitment: A conceptual model developed from an integrative review of the research. Human Resource Development Review, 7(3), 339-357.

Fornes, S. L., \& Rocco, T. S. (2004). Commitment elements reframed (Antecedents \& Consequences) for Organizational Effectiveness. Online Submission. Paper presented at the Academy of Human Resource Development International Conference (AHRD) p391-398 (Symp. 19-3) Retrieved from https://files.eric.ed.gov/fulltext/ED492195.pdf

Furlich, S. A. (2016). Understanding instructor nonverbal immediacy, verbal immediacy, and student motivation at a small liberal arts university. Journal of the Scholarship of Teaching and Learning, 16(3), 11-22.

Garcia, G. F. (2015). The relationship between self-efficacy and employee commitment among perfusionists (Doctoral dissertation). Retrieved from https://scholarworks.waldenu.edu/cgi/viewcontent.cgi?article=2308\&context=dissertations

Gonzalez, J. A., Jr. (2001). Personal and social identity in organizations: A study of organizational commitment (Order No. 3020039). Available from ProQuest Central. (304769091). Retrieved from http://search.proquest.com/docview/304769091 ?accountid=31259 


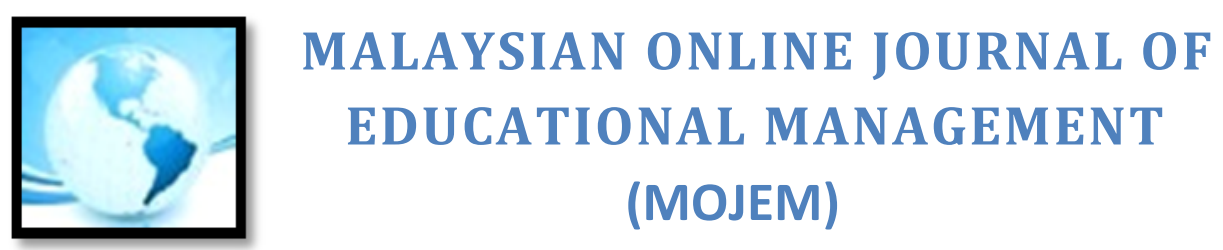

Hair, J. F., Sarstedt, M., Ringle, C. M., \& Mena, J. A. (2012). An assessment of the use of partial least squares structural equation modeling in marketing research. Journal of the Academy of Marketing Science, 40(3), 414-433.

Hooper, D., Coughlan, J., \& Mullen, M. R. (2008). Structural equation modelling: Guidelines for determining model fit. The Electronic Journal of Business Research Methods, 6(1), $53-60$.

Hsieh, B. (2015). The importance of orientation: Implications of professional identity on classroom practice and for professional learning. Teachers and Teaching, 21(2), 178-190.

Huff, L., \& Kelley, L. (2003). Levels of organizational trust in individualist versus collectivist societies: A seven-nation study. Organization Science, 14(1), 81-90.

Jacobson, D. A. (2016). Causes and effects of teacher burnout (Doctoral dissertation). Retrieved from https://scholarworks.waldenu.edu/cgi/viewcontent.cgi?referer=https://scholar.google.com/\&httpsredir $=1 \&$ article $=3938 \&$ context $=$ dissertations

Jaros, S. (2007). Meyer and Allen model of organizational commitment: Measurement issues. The Institute of Chartered Financial Analysts of India Journal of Organizational Behaviour, 6(4), 7-25.

Jehanzeb, K., Rasheed, A., \& Rasheed, M. F. (2013). Organizational commitment and turnover intentions: Impact of employee's training in private sector of Saudi Arabia. International Journal of Business and Management, 8(8), 79-90. Retrieved from http://www.ccsenet.org/journal/index.php/ijbm/article/view/23349

Johnson, B., \& Christensen, L. (2008). Educational research: Quantitative, qualitative, and mixed approaches. USA: SAGE Publications.

Johnson, R. E., Chang, C. H., \& Yang, L. Q. (2010). Commitment and motivation at work: The relevance of employee identity and regulatory focus. Academy of Management Review, 35(2), 226-245.

Johnson, Z. D., Claus, C. J., Goldman, Z. W., \& Sollitto, M. (2017). College student misbehaviors: An exploration of instructor perceptions. Communication Education, 66(1), 54-69.

Kinjerski, V., \& Skrypnek, B. J. (2006). Creating organizational conditions that foster employee spirit at work. Leadership \& Organization Development Journal, 27(4), 280-295.

Klassen, R. M., \& Chiu, M. M. (2010). Effects on teachers' self-efficacy and job satisfaction: Teacher gender, years of experience, and job stress. Journal of Educational Psychology, 102(3), 741-756. Retrieved from http://citeseerx.ist.psu.edu/viewdoc/download?doi=10.1.1.893.3574\&rep=rep1\&type=pdf

Larrivee, B. (2012). Cultivating teacher renewal: Guarding against stress and burnout. USA: R\&L Education. Retrieved from https://www.researchgate.net/profile/Andrea_Hyde/publication/274636094_Review_of_Cultivating_Te acher_Renewal_Guarding_Against_Stress_and_Burnout_by_Barbara_Larrivee/links/55240b0f0cf22e181 e7386be/Review-of-Cultivating-Teacher-Renewal-Guarding-Against-Stress-and-Burnout-by-BarbaraLarrivee.pdf

Laurinolli, H. (2010). Nuoret eivät sitoudu [Young people do not commit]. Retrieved from https://aikalainen.uta.fi/2010/12/08/nuoret-eivat-sitoudu/ 


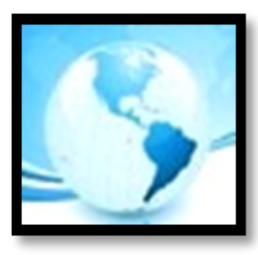

Lopez, E. (2004). McKeachie's teaching tips: Strategies, research, and theory for college and university teachers. The Review of Higher Education, 27(2), 283-284.

Mahdi, A., Ismail, N. S., Jugie, O. S., \& Sari, S. (2017). A study on relationship between five-factor model of personality traits and commitment among support staff at Batu Lintang, Kuching, Sarawak. Paper presented at the ICOPS2017 eProceedings, 320-332. Retrieved from https://www.researchgate.net/profile/Nur_Zafifa_Kamarunzaman/publication/322076604_FULL_PAPER _ICOPSS2017/links/5a43229e0f7e9ba868a48d42/FULL-PAPER-ICOPSS2017.pdf\#page=320

Mehrabian, A. (1981). Silent messages: Implicit communications of emotions and attitudes. Belmont, CA: Wadsworth.

Meyer, J. P., \& Allen, N. J. (1997). Commitment in the workplace: Theory, research, and application. USA: SAGE Publications.

Mojavezi, A., \& Tamiz, M. P. (2012). The impact of teacher self-efficacy on the students' motivation and achievement. Theory \& Practice in Language Studies, 2(3), 483-491. Retrieved from http://www.academypublication.com/issues/past/tpls/vol02/03/08.pdf

Mullane, R. R. (2014). Student's perception of teacher immediacy behaviours on student success and retention (Doctoral dissertation). Retrieved from https://pdfs.semanticscholar.org/133b/dcd89ef79a48aca28ed1ba25025ad4178a3c.pdf

Murthy, R. K. (2014). Self-efficacy, work engagement, and organizational commitment. Global Journal of Multidisciplinary Studies, 3(6), 438-448. Retrieved from http://www.journal.edwin.co.in/index.php/GJMS/article/view/209

Nicholson, W. M. (2009). Leadership practices, organizational commitment, and turnover intentions: A correlational study in a call center (Doctoral dissertation). Retrieved from https://media.proquest.com/media/pq/classic/doc/1683462441/fmt/ai/rep/NPDF?_s=gal148aLk8QZuxv 7PI90Gyd0wZs\%3D

Pan, Y. H. (2014). Relationships among teachers' self-efficacy and students' motivation, atmosphere, and satisfaction in physical education. Journal of Teaching in Physical Education, 33(1), 68-92.

Pianta, R. C., Hamre, B. K., \& Allen, J. P. (2012). Teacher-student relationships and engagement: Conceptualizing, measuring, and improving the capacity of classroom interactions. In Handbook of research on student engagement (pp. 365-386). Springer, Boston, MA.

Prastika, L. M. (2017). Reasons behind inappropriate students' behaviour in the English classroom (Doctoral dissertation). $\quad$ Retrieved from http://repository.uksw.edu/bitstream/123456789/14458/2/T1_112013006_Full\%20text.pdf

Powell, R., Cantrell, S. C., \& Adams, S. (2001). Saving Black Mountain: The promise of critical literacy in a multicultural democracy. The Reading Teacher, 54(8), 772-781.

Reyes, M. R., Brackett, M. A., Rivers, S. E., White, M., \& Salovey, P. (2012). Classroom emotional climate, student engagement, and academic achievement. Journal of Educational Psychology, 104(3), 700-712. Retrieved from http://psycnet.apa.org/record/2012-05721-001 


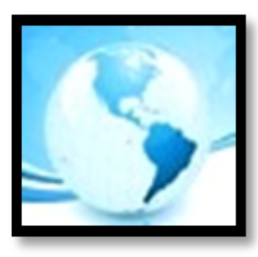

\section{MALAYSIAN ONLINE JOURNAL OF EDUCATIONAL MANAGEMENT (MOJEM)}

Richardson, G. E. (2011). Teacher efficacy and its effect on the academic achievement of African American students (Doctoral dissertation). Retrieved from http://greenleaf.edu/pdf/george_richardson.pdf

Roberts, A., \& Friedman, D. (2013). The impact of teacher immediacy on student participation: An objective crossdisciplinary examination. International Journal of Teaching and Learning in Higher Education, 25(1), 3846.

Rodríguez, J. I., Plax, T. G., \& Kearney, P. (1996). Clarifying the relationship between teacher nonverbal immediacy and student cognitive learning: Affective learning as the central causal mediator. Communication Education, 45(4), 293-305.

Ryan, A. M., Kuusinen, C. M., \& Bedoya-Skoog, A. (2015). Managing peer relations: A dimension of teacher selfefficacy that varies between elementary and middle school teachers and is associated with observed classroom quality. Contemporary Educational Psychology, 41, 147-156. Retrieved from https://www.sciencedirect.com/science/article/pii/S0361476X1500003X

Shahzad, K., Rehman, K. U., \& Abbas, M. (2010). HR practices and leadership styles as predictors of employee attitude and behaviour: Evidence from Pakistan. European Journal of Social Sciences, 14(3), 417-426.

Skaalvik, E. M., \& Skaalvik, S. (2007). Dimensions of teacher self-efficacy and relations with strain factors, perceived collective teacher efficacy, and teacher burnout. Journal of Educational Psychology, 99(3), 611-625. Retrieved from https://www.researchgate.net/profile/Einar_Skaalvik/publication/232591575_Dimensions_of_Teacher_ Self-

Efficacy_and_Relations_With_Strain_Factors_Perceived_Collective_Teacher_Efficacy_and_Teacher_Bur nout/links/00463522de15c42f53000000.pdf

Schwarzer, R., \& Hallum, S. (2008). Perceived teacher self-efficacy as a predictor of job stress and burnout: Mediation analyses. Applied Psychology, 57(1), 152- 171.

Suryani, I. (2018). Factors affecting organizational commitment. Jurnal Manajemen dan Inovasi, 9(1), 26-34. Retrieved from http://www.jurnal.unsyiah.ac.id/JInoMan/article/view/11418

Tabuso, J. (2007). Organizational commitment of the faculty of the Divine World College in Vigan. Retrieved from file:///C:/Users/THIS\%20PC/Downloads/8-20-1- PB.pdf.

Thoits, P. A. (2003) Personal agency in the accumulation of multiple role-identities. In Burke P. J., Owens T. J., Serpe R. T., Thoits P. A. (Eds.), Advances in identity theory and research. (pp. 179-194). Boston, MA: Springer.

Tolentino, R. C. (2013). Organizational commitment and job performance of the academic and administrative personnel. International Journal of Information Technology and Business Management, 15(1), 51-59. Retrieved from http://jitbm.com/JITBM\%2015th\%20volume/5\%200rganization\%20Commitment.pdf

Tschannen-Moran, M., \& Hoy, A. W. (2001). Teacher efficacy: Capturing an elusive construct. Teaching and Teacher $\begin{array}{llll}\text { Education, } & \text { 17(7), } & \text { Retrieved from }\end{array}$ https://wps.ablongman.com/wps/media/pbjects/2347/2404137/Megan_anita.pdf 


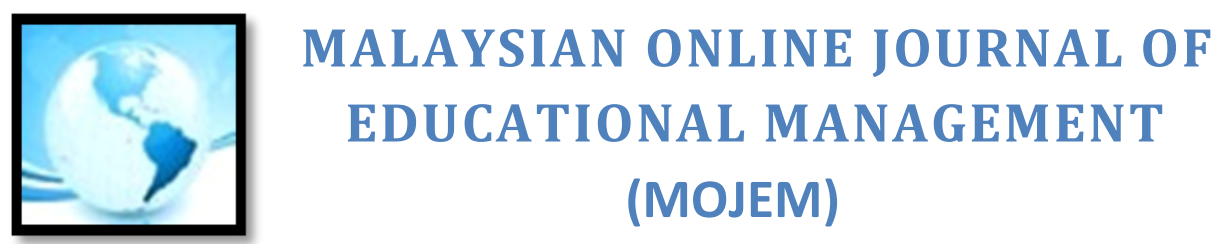

Ulrich, D., \& Smallwood, N. (2003). Why the bottom line isn't!: How to build value through people and organization. New Jersey: John Wiley \& Sons.

Velez, J. J., \& Cano, J. (2008). The relationship between teacher immediacy and student motivation. Journal of Agricultural Education, 49(3), 76-86.

Veugelers, W. (2008). Moral values in teacher education. Paper presented at the 1st Symposium on Moral and Democratic Education, $24-27$ August 2008, Florina, Greece. Retrieved from http://www.eled.uowm.gr/sig13/fulltexts/Paper15.pdf on March 1, 2017.

Witt, P. L., Wheeless, L. R., \& Allen, M. (2004). A meta-analytical review of the relationship between teacher immediacy and student learning. Communication Monographs, 71(2), 184-207.

Witt, P. L., Schrodt, P., Wheeless, V. E., \& Bryand, M. C. (2014). Students' intent to persist in college: Moderating the negative effects of receiver apprehension with instructor credibility and nonverbal immediacy. Communication Studies, 65(3), 330-352.

York, D. (2015). Non-verbal immediacy's role in student learning. Journal of Media and Communication Studies, 7(1), 1-7.

Yuan, K. H., \& Hayashi, K. (2010). Fitting data to model: Structural equation modeling diagnosis using two scatter plots. Psychological Methods, 15(4), 335-351. Retrieved from https://www.researchgate.net/profile/KeHai_Yuan/publication/46379474_Fitting_Data_to_Model_Structural_Equation_Modeling_Diagnosis_Usi ng_Two_Scatter_Plots/links/0c960534340da65bd1000000/Fitting-Data-to-Model-Structural-EquationModeling-Diagnosis-Using-Two-Scatter-Plots.pdf 